\title{
Regional and Cellular Patterns of reelin mRNA Expression in the Forebrain of the Developing and Adult Mouse
}

\author{
Soledad Alcántara, ${ }^{1,2}$ Mónica Ruiz, ${ }^{1}$ Gabriella D’Arcangelo,, ${ }^{3}$ Frederic Ezan, ${ }^{2}$ Luis de Lecea, ${ }^{4}$ Tom Curran, ${ }^{3}$ \\ Constantino Sotelo, ${ }^{2}$ and Eduardo Soriano ${ }^{1}$ \\ ${ }^{1}$ Department of Animal and Plant Cell Biology, Faculty of Biology, University of Barcelona, Barcelona 08028, Spain, \\ 2Institut National de la Santé et de la Recherche Médicale U-106, Hôpital de la Salpetrière, 75651 Paris, France, \\ ${ }^{3}$ Department of Developmental Neurobiology, St. Jude Children's Research Hospital, Memphis, Tennessee 38105, and \\ ${ }^{4}$ Department of Molecular Biology, The Scripps Research Institute, La Jolla, California 92037
}

The reelin gene encodes an extracellular protein that is crucial for neuronal migration in laminated brain regions. To gain insights into the functions of Reelin, we performed highresolution in situ hybridization analyses to determine the pattern of reelin expression in the developing forebrain of the mouse. We also performed double-labeling studies with several markers, including calcium-binding proteins, GAD65/67, and neuropeptides, to characterize the neuronal subsets that express reelin transcripts. reelin expression was detected at embryonic day 10 and later in the forebrain, with a distribution that is consistent with the prosomeric model of forebrain regionalization. In the diencephalon, expression was restricted to transverse and longitudinal domains that delineated boundaries between neuromeres. During embryogenesis, reelin was detected in the cerebral cortex in Cajal-Retzius cells but not in the GABAergic neurons of layer I. At prenatal stages, reelin was also expressed in the olfactory bulb, and striatum and in re- stricted nuclei in the ventral telencephalon, hypothalamus, thalamus, and pretectum. At postnatal stages, reelin transcripts gradually disappeared from Cajal-Retzius cells, at the same time as they appeared in subsets of GABAergic neurons distributed throughout neocortical and hippocampal layers. In other telencephalic and diencephalic regions, reelin expression decreased steadily during the postnatal period. In the adult, there was prominent expression in the olfactory bulb and cerebral cortex, where it was restricted to subsets of GABAergic interneurons that co-expressed calbindin, calretinin, neuropeptide $\mathrm{Y}$, and somatostatin. This complex pattern of cellular and regional expression is consistent with Reelin having multiple roles in brain development and adult brain function.

Key words: in situ hybridization; neural development; corticogenesis; neuronal migration; prosomeric subdivisions; CajalRetzius cells; GABAergic interneurons
Neuronal migration is an essential step in the genesis of the nervous system (Rakic, 1990; Hatten, 1993). In the cerebral cortex, postmitotic neurons follow an ordered "inside-out" sequence of migration that determines the normal layering and cytoarchitectonics (Angevine and Sidman, 1961; Rakic, 1974, 1988). Abnormal migration leading to malpositioning of cortical neurons results in severe cytoarchitectonic malformations with functional consequences manifested as cognitive deficits and mental retardation (Caviness and Sidman, 1973; Barth, 1987; Goffinet, 1992; Eksloglu et al., 1996; des Portes et al., 1998; Gleeson et al., 1998).

Until recently, very little was known about the molecules that control neuronal migration. Previous studies implicated astrotac-

Received May 1, 1998; revised July 8, 1998; accepted July 13, 1998.

This work was supported by Grants SAF98-106 and SAF97-1429-E (Comisión Interministerial de Ciencia y Tecnología, Spain) and by the Ramón Areces Foundation (Spain) to E.S., by Institut National de la Santé et de la Recherche Médicale financial support to C.S., and by National Institutes of Health Cancer Center Support (CORE P30CA21765 and RO1 NS36558) and the American Lebanese Syrian Associated Charities to T.C. T.C. and E.S. were supported by the Human Frontier Science Program Organization (RG0067/1998-B). S.A. is a recipient of Comisión Interdepartamental de Recerca i Technología and Ministerio de Educacion y Ciencia postdoctoral fellowships. We are indebted to Dr. A. Tobin (University of California Los Angeles) for the generous gift of GAD 65/67 clones and to R. Rycroft for editorial assistance.

Correspondence should be addressed to Dr. Eduardo Soriano, Department of Animal and Plant Cell Biology, Faculty of Biology, University of Barcelona, Diagonal 645, Barcelona 08028, Spain.

Copyright (ㄷ) 1998 Society for Neuroscience $\quad 0270-6474 / 98 / 187779-21 \$ 05.00 / 0$ tin and radial glia proteins associated with focal adhesions as molecules necessary for sustaining neuronal migration (Fishell and Hatten, 1991; Cameron and Rakic, 1994; Anton et al., 1996; Zheng et al., 1996). Other analyses also implicated neuregulin/ ErbB2 (Anton et al., 1997; Rio et al., 1997), the NMDA glutamate receptor (Komuro and Rakic, 1993), brain lipid-binding protein (Feng et al., 1994), and netrin 1 (Serafini et al., 1996; Ackerman et al., 1997) in migration.

The reeler mutation causes severe migration abnormalities in many brain areas in the mouse, particularly in laminated regions such as the neocortex, hippocampus, and cerebellum (Caviness and Sidman, 1973; Mariani et al., 1977; Goffinet, 1980, 1992; Derer, 1985; Rakic and Caviness, 1995). reelin, the gene disrupted in the reeler mutation, encodes a large extracellular protein containing regions of similarity with F-spondin, restrictin, tenascin, and the integrin $\beta$-chain family (D'Arcangelo et al., 1995, 1997; Hirotsune et al., 1995). Previous studies have shown that, in the cerebral cortex, reelin is expressed in the developing layer I by Cajal-Retzius (CR) cells (D'Arcangelo et al., 1995; Hirotsune et al., 1995; Ogawa et al., 1995; Nakajima et al., 1997), which are a special class of pioneer neurons (Marín-Padilla, 1971, 1972, 1984, 1998; Edmunds and Parnavelas, 1982; Derer and Derer, 1990, 1992; Soriano et al., 1994; Del Río et al., 1995, 1997). The severe phenotype of the reeler mutant mouse and the finding that Reelin is necessary for the histotypic organization of reaggregation cultures (Ogawa et al., 1995) emphasize the relevance of this 


\begin{tabular}{|c|c|c|c|}
\hline & E10 & E11 & E12 \\
\hline \multicolumn{4}{|l|}{ Secondary prosencephalon } \\
\hline \multicolumn{4}{|l|}{ Prosomere 6} \\
\hline Olfactory bulb & + & ++ & +++ \\
\hline Lateral septum & - & - & - \\
\hline Medial septum/diagonal band & - & + & + \\
\hline \multicolumn{4}{|l|}{ Prosomere 5} \\
\hline Neocortex & + & ++ & +++ \\
\hline Striatal differentiated field & - & + & + \\
\hline Amygdala & - & + & + \\
\hline Anterior hypothalamus & - & + & + \\
\hline Hypothalamic cell cord & - & ++ & ++ \\
\hline \multicolumn{4}{|l|}{ Prosomere 4} \\
\hline Archicortex & + & ++ & +++ \\
\hline Supraoptic/paraventricular hypothalamus & - & + & + \\
\hline Posterior entopeduncular area & - & ++ & ++ \\
\hline \multicolumn{4}{|l|}{ Diencephalon } \\
\hline \multicolumn{4}{|l|}{ Prosomere 3} \\
\hline Ventral thalamus & - & ++ & ++ \\
\hline Zona limitans intrathalamica & - & ++ & +++ \\
\hline \multicolumn{4}{|l|}{ Prosomere 2} \\
\hline Dorsal thalamus & - & - & - \\
\hline Epithalamus & - & + & + \\
\hline \multicolumn{4}{|l|}{ Prosomere 1} \\
\hline Pretectum & - & ++ & ++ \\
\hline
\end{tabular}

Low $(+)$, moderate $(++)$, and high $(+++)$ levels of reelin expression are shown. No detectable levels of expression are also indicated $(-)$.

protein for neuronal migration. Moreover, Reelin influences the growth of hippocampal afferents, implying a role in axonal growth and guidance (Del Río et al., 1997). The observation that mice lacking the $c d k-5, p 35$, and mdab1 genes, which encode signal transduction-associated proteins, have migratory deficits similar to those in reeler (Oshima et al., 1996; Chae et al., 1997; Howell et al., 1997a,b; Sheldon et al., 1997; Ware et al., 1997) suggests that Reelin functions are mediated by as yet uncharacterized receptor(s) or Reelin-binding protein(s).

Two studies have mapped the pattern of expression of reelin during brain development (Ikeda and Terashima, 1997; Schiffmann et al., 1997), emphasizing the lack of correlation between sites of reelin expression and the reeler phenotype. In addition, a recent study reports reelin mRNA and protein in GABAergic neurons of the adult cerebral cortex (Pesold et al., 1998). To gain insight into the developmental functions of Reelin, here we used a digoxigenin-labeled riboprobe to provide high-resolution in situ hybridization analyses of the pattern of reelin expression in the forebrain of the mouse. We also performed double-labeling studies with several neurochemical markers to characterize the neuronal cell classes that express reelin.

\section{MATERIALS AND METHODS}

Animals. OF1 embryos and postnatal albino mice (Iffa Credo, Lyon, France) were used in this study. The mating day was considered embryonic day 0 (E0), and the day of birth was considered postnatal day 0 (P0). The following developmental stages were studied: E10, E11, E12, E14, E16, E18, P0, P5, P10, P15, P21, and adult (three to nine animals each). After ether anesthesia of the dams, E10-E12 embryos were dissected out and fixed by immersion in $4 \%$ paraformaldehyde in $0.1 \mathrm{M}$ phosphate buffer, $\mathrm{pH}$ 7.3. Embryos older than E14 and postnatal animals were transcardially perfused with the above fixative, and their brains were post-fixed. Thereafter, the brains were cryoprotected in $30 \%$ sucrose and frozen on dry ice. Coronal, sagittal, and horizontal sections (thickness: $80 \mu \mathrm{m}, \mathrm{E} 10-\mathrm{E} 12 ; 60 \mu \mathrm{m}, \mathrm{E} 14-\mathrm{E} 18 ; 50 \mu \mathrm{m}, \mathrm{P} 0-\mathrm{P} 10 ; 30 \mu \mathrm{m}, \mathrm{P} 15-$ adult) were collected in a cryoprotectant solution ( $30 \%$ glycerol, $30 \%$ ethylene glycol, $40 \% 0.1 \mathrm{M} \mathrm{PBS}$ ), and stored at $-30^{\circ} \mathrm{C}$ until use.

In situ hybridization and immunocytochemistry. In situ hybridization was performed on free-floating sections essentially as described (de Lecea et al., 1994, 1997). Sections were permeabilized in $0.2-0.5 \%$ Triton X-100 (15 min), treated with $2 \% \mathrm{H}_{2} \mathrm{O}_{2}(15 \mathrm{~min})$, deproteinized with $0.2 \mathrm{~N} \mathrm{HCl}(10 \mathrm{~min})$, acetylated with acetic anhydride $(0.25 \%$ in 0.1 $\mathrm{M}$ triethanolamine hydrochloride; $\mathrm{pH} 8$ ), fixed in $4 \%$ paraformaldehyde (10 $\mathrm{min})$, and blocked in $0.2 \%$ glycine $(5 \mathrm{~min})$. Thereafter, sections were prehybridized at $60^{\circ} \mathrm{C}$ for $3 \mathrm{hr}$ in a solution containing $50 \%$ formamide, $10 \%$ dextran sulfate, $5 \times$ Denhardt's solution, $0.62 \mathrm{M} \mathrm{NaCl}, 10 \mathrm{~mm}$ EDTA, $20 \mathrm{~mm}$ PIPES, pH 6.8, $50 \mathrm{~mm}$ DTT, $250 \mu \mathrm{g} / \mathrm{ml}$ yeast t-RNA, and $250 \mu \mathrm{g} / \mathrm{ml}$ denatured salmon sperm DNA. A reelin riboprobe was labeled with digoxigenin-d-UTP (Boehringer Mannheim, Mannheim, Germany) by in vitro transcription of a cDNA fragment encoding mouse reelin (D'Arcangelo et al., 1995) using T3 polymerase (Ambion, Austin, TX). Labeled antisense cRNA was added to the prehybridization solution $(500$ $\mathrm{ng} / \mathrm{ml}$ ), and hybridization was performed at $60^{\circ} \mathrm{C}$ overnight. Sections were then washed in $2 \times \operatorname{SSC}(30 \mathrm{~min}$, room temperature), digested with $20 \mathrm{mg} / \mathrm{ml} \mathrm{RNase}$ A $\left(37^{\circ} \mathrm{C}, 1 \mathrm{hr}\right)$, and washed in $0.5 \times \mathrm{SSC} / 50 \%$ formamide $\left(4 \mathrm{hr}, 55^{\circ} \mathrm{C}\right)$ and in $0.1 \times \mathrm{SSC} / 0.1 \%$ sarkosyl $\left(1 \mathrm{hr}, 60^{\circ} \mathrm{C}\right)$. After sections were rinsed in Tris-buffered saline (TBS)/0.1\% Tween $20(15$ $\mathrm{min})$, they were blocked in $10 \%$ normal goat serum $(2 \mathrm{hr})$ and incubated overnight with an alkaline phosphatase-conjugated antibody to digoxigenin (1:2000; Boehringer Mannheim). After they were washed, sections were developed with nitroblue tetrazolium (NBT) and 5-bromo-4chloro-3-indolyl phosphate (BCIP) (Life Technologies, Gaithersburg, MD), mounted on gelatinized slides, and coverslipped with Mowiol.

Alternatively, hybridized sections were immunolabeled with different antibody cell markers after NBT/BCIP development. After several washes in PBS, sections were incubated overnight with rabbit antibodies against calbindin (1:6000), calretinin (1:3000), parvalbumin (1:6000) (all from Swant antibodies, Bellizona, Switzerland), neuropeptide Y (NPY; 1:2000), vasoactive intestinal peptide (VIP; 1: 2000) (both from CRB, Northwich Cheshire, UK), somatostatin (1:1000; Dakkopats, Santa Barbara, CA) and cholecystokinin (CCK; 1:2000, CRB). Primary antibodies were visualized using a biotinylated goat anti-rabbit antibody $(1: 200)$ and the avidin-biotin peroxidase complex (Vector Labs, Burlingame, CA). Peroxidase reaction was developed using diaminobenzidine and $\mathrm{H}_{2} \mathrm{O}_{2}$.

Double-labeling in situ hybridization. We performed double-label in situ hybridization on free-floating sections essentially as described (de Lecea et al., 1997). Briefly, a cDNA fragment encoding mouse reelin (D’Arcangelo et al., 1995) was transcribed in vitro using T3 RNA polymerase (Ambion) and ${ }^{35} \mathrm{~S}$-UTP (Amersham Ibérica). The two isoforms of rat glutamic acid decarboxylase [GAD65 and GAD67, generously provided by Dr. Allan Tobin (University of California Los Angeles)] were labeled with digoxigenin-dUTP (Boehringer Mannheim) and T3 RNA polymerase. The tissue was pretreated as described above and $1.5 \times 10^{7} \mathrm{cpm} / \mathrm{ml}$ of ${ }^{35} \mathrm{~S}$-labeled reelin mRNA and $50 \mathrm{ng} / \mathrm{ml}$ of digoxigenin-labeled GAD65 or GAD67 were added. After washing at high stringency in the presence of $10 \mathrm{~mm} \beta$-mercaptoethanol, sections were incubated with the alkaline phosphatase-conjugated antibody and developed as described above. Sections were then mounted on coated slides and dipped in Ilford K5 autoradiographic emulsion, exposed for 5 weeks at $4^{\circ} \mathrm{C}$, and developed with Kodak D19.

GAD67 always gave a stronger signal than GAD65. However, the patterns of expression were so similar that both were considered as GAD65/67 expression.

Controls. Control hybridizations, including hybridization with sense digoxigenin- or ${ }^{35}$ S-labeled riboprobes or RNase A digestion before hybridization, prevented alkaline phosphatase staining and autoradiographic signals above background levels. For immunocytochemical controls, omission of the primary antibodies prevented diaminobenzidine staining.

Data analysis. Sections were examined on a Zeiss Axiophot microscope (Oberkochen, Germany). The delimitation of regional and laminar boundaries was performed according to Sidman et al. (1971), Zilles (1985), and Paxinos et al. (1994). The radial distribution of reelinexpressing cells and double-labeled neurons was determined in vertical strips (500 $\mu \mathrm{m}$ wide) covering the entire cortical thickness in the first somatosensory area and in the hippocampus. For each neurochemical 


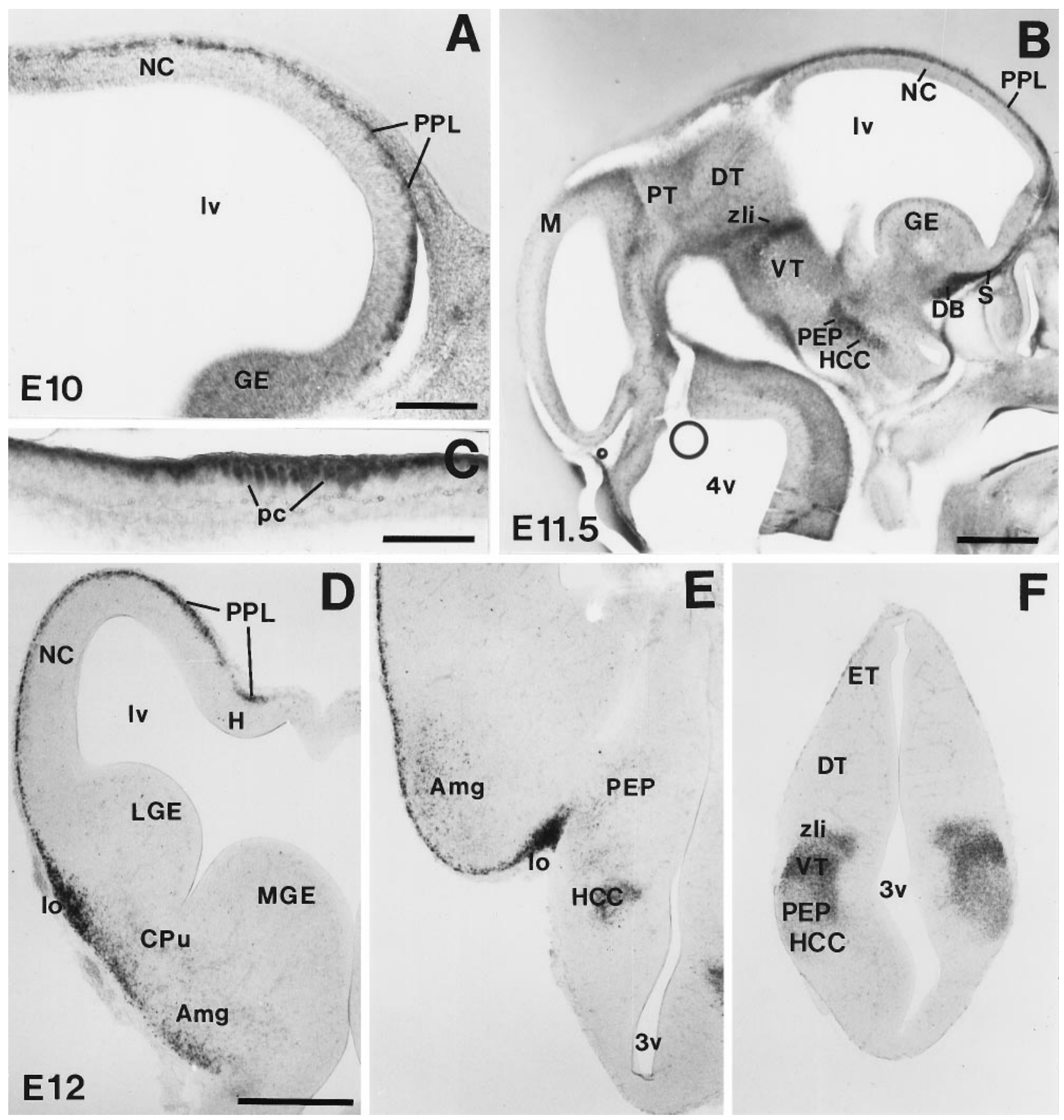

Figure 1. reelin mRNA expression during early embryonic development. A, Parasagittal section of the telencephalon at E10, showing reelin expression in the outermost preplate layer $(P P L)$ of the neocortex $(N C)$. B, Parasagittal section showing distribution of reelin mRNA in the telencephalon and diencephalon at E11.5. reelin is strongly expressed in the $P P L$, in the anlages of the septum $(S)$ and diagonal band $(D B)$ complex, in a longitudinal band covering the posterior entopeduncular area $(P E P)$ and the hypothalamic cell cord $(H C C)$, and in three transverse diencephalic domains corresponding to the zona limitans intrathalamica $(z l i)$, the border between dorsal thalamus $(D T)$ and pretectum $(P T)$, and in the posterior commissure $(p c)$, at the border between the mesencephalon $(M)$ and the $P T$. $C$, High-magnification photomicrograph showing labeled cells at the posterior commissure ( $p c$ ). $D-F$, Coronal sections of an E12 embryo showing the distribution of reelin transcripts at three different rostrocaudal levels $(D$, rostral; $F$, caudal). Note the prominent reelin expression associated to the lateral olfactory tract $(l o$ in $D, E)$ and the labeled cells in the presumptive caudate-putamen $(C P u)$, amygdala (Amg), and ventral thalamus $(V T)$. DT, Dorsal thalamus; $E T$, epithalamus; $G E$, ganglionic eminence; $H$, hippocampus; $l v$, lateral ventricle; $L G E$, lateral ganglionic eminence; $M G E$, medial ganglionic eminence; $3 v$, third ventricle; $4 v$, fourth ventricle. Scale bars: $A, C, 150 \mu \mathrm{m} ; B, D-F, 500 \mu \mathrm{m}$.

marker, reelin-expressing cells and immunoreactive cells displaying positive and negative hybridization were counted in eight vertical strips from two adult mice. Results were expressed as mean \pm SD and as percentage of colocalization. Data were compared by ANOVA and post hoc $t$ tests.

\section{RESULTS}

reelin transcripts were first detected at E10 both in the telencephalon and in the diencephalon. At E11-E12, there was an overall 


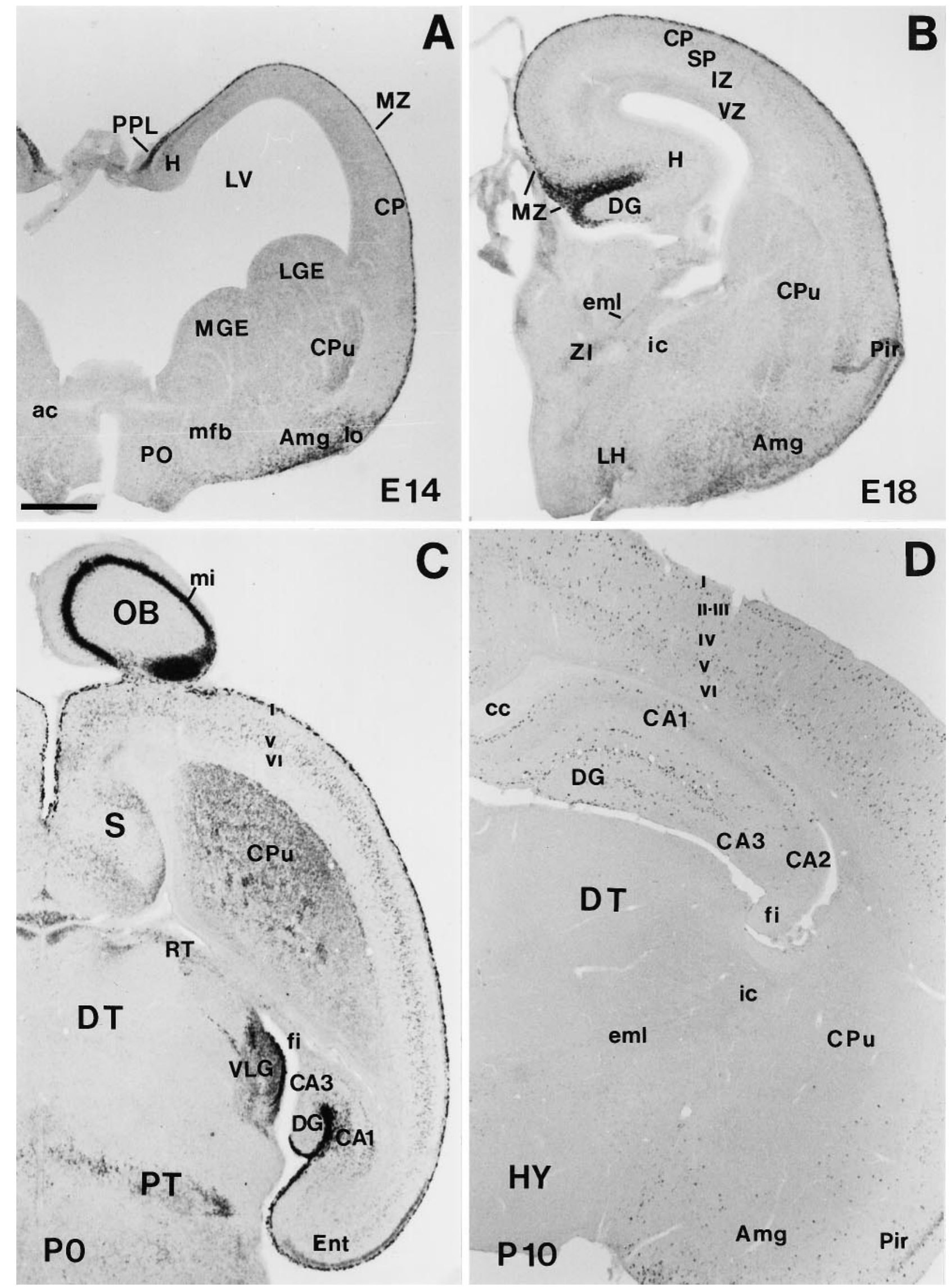


increase in the expression of reelin in many telencephalic and diencephalic regions (Table 1, Fig. 1). Maximum levels occurred between E14 and P5, when prominent labeling was detected in the cerebral cortex, including the hippocampus, striatum, and olfactory bulb, and in discrete nuclei of the basal forebrain, thalamus, and hypothalamus (Table 2, Fig. 2). Levels of expression were always higher in the cerebral cortex and olfactory bulb than in the remaining forebrain regions. In the cerebral cortex, expression was detected in the marginal zone-layer I, but also in cells in the cortical plate. Between P5 and P21, reelin expression decreased in all forebrain regions (Fig. 2). In the adult, however, weak reelin signals persisted in the cerebral cortex and olfactory bulb and in some basal forebrain nuclei.

\section{Early expression of reelin mRNA in the forebrain}

The early distribution of reelin mRNAs is described according to the prosomeric model of forebrain organization (Table 1) (Puelles and Rubenstein, 1993). reelin transcripts were always detected within differentiating fields, and no detectable signals were found in the germinal matrices.

At E10, weak expression was observed in the surface of the alar plate at the rostral part of the secondary prosencephalon (Prosomeres 4-6), corresponding to the presumptive olfactory bulb, neocortex, archicortex, and rhinencephalon (Table 1, Fig. 1A). At E11-E12, reelin expression became more intense in the olfactory bulb and telencephalon, where a band of heavily labeled cells covered the entire telencephalic vesicles, including the ventralmost aspects and the archicortex. In addition, variable levels of expression were found in the differentiated fields of the prospective medial septum/diagonal band complex, striatum, and amygdala. In the hypothalamic anlage, a longitudinal domain of strong reelin expression, roughly corresponding to the hypothalamic cell cord and posterior entopeduncular area, was observed. reelinexpressing cells were also found in the supraoptic/paraventricular area and in the anterior hypothalamus (Table 1, Fig. $1 B-F$ ).

No reelin transcripts were detected in the dorsal thalamus at E10-E12. In contrast, reelin mRNA expression in the diencephalon roughly delineated the transverse boundaries between prosomeres (Fig. $1 B, E, F$ ). Thus, in the ventral thalamus, reelin hybridization signals were intense in the presumptive ventral lateral geniculate nucleus as well as in the zona limitans intrathalamica, two regions that delimit the dorsal thalamus (Prosomere 2)/ventral thalamus (Prosomere 3 ) boundary. reelin hybridization was also detected in the presumptive reticular nucleus and in the zona incerta (ventral thalamus). In addition, very faint expression was found in the differentiated fields of the epithalamus (dorsal region of Prosomere 2) (Table 1).

Two transversal domains of expression were found in the pretectum at E11-E12 that corresponded to the boundary between the presumptive dorsal thalamus (Prosomere 2) and the pretectum (Prosomere 1), and to the boundary between the pretectum and the mesencephalon (diencephalon/mesencephalon boundary). Here, reelin was expressed in a band of superficial neurons running along the posterior commissure (Mastick and Easter, 1996) (Fig. 1B,C).

In summary, at E10-E12 reelin transcripts are expressed in spatially restricted transverse and longitudinal domains in the alar plate of the secondary prosencephalon (Prosomeres 6-4) and in the prospective diencephalon (Prosomeres 1-3).

\section{reelin mRNA expression in the developing marginal zone-layer I of the neocortex}

A major site of reelin expression was the marginal zone-layer I of the cerebral cortex [see also D'Arcangelo et al. (1995); Hirotsune et al. (1995)]. At E11-E12 (preplate stage), reelin transcripts were detected in a thin layer of cells at the cortical surface that corresponded to the outermost aspect of the preplate, where the CR cells are located (Marin-Padilla, 1972; Derer and Derer, 1990; De Carlos and O’Leary, 1992; Del Río et al., 1995). These positive cells were arranged in a continuous band that covered the entire telencephalic vesicles, including the prospective neocortex, hippocampal region, entorhinal cortex, and piriform area, but also the anlage of the septal region (Fig. 1D,E). At E14, when the cortical plate has emerged, reelin-expressing cells were present exclusively in the outer half of the marginal zone-layer I (Fig. $2 A$ ). These intensely labeled cells had large perikarya and horizontal shapes. The pattern of hybridization in the marginal zonelayer I of the neocortex remained essentially similar at E16-P0, with intensely labeled cells in the outer half of this layer (Figs. $2 B, C, 3 A)$.

To substantiate the notion that these neurons were CR cells, reelin hybridized sections were treated with calretinin antibodies, a marker for murine CR cells (Del Río et al., 1995, 1997). At E14, most reelin-positive neurons were also calretinin-positive, but a few cells exclusively displayed reelin labeling, suggesting that reelin expression precedes calretinin staining (data not shown). At E16-P0 there was a complete colocalization of reelin mRNA and calretinin, with double-labeled neurons displaying the typical features of murine CR cells (see Fig. 4A,B,E).

We also stained reelin hybridized sections with calbindin antibodies, which label the intrinsic population of GABAergic neurons in the marginal zone-layer I located at the deeper half of this layer (Del Río et al., 1992, 1995; Brunstrom et al., 1997). At no stage (E14-P0) did calbindin-positive neurons in layer I express reelin (see Fig. $4 C$ ). This notion was substantiated by double-hybridization staining with reelin and GAD65/67 riboprobes. At prenatal stages, GAD65/67 hybridization faintly labeled a band of neurons in the inner marginal zone (see also Fig. $4 D$ ), far away from the layer of reelin-expressing neurons in the outer marginal zone. Thus, at embryonic and perinatal stages, reelin transcripts in the marginal zone-layer I of the neocortex are expressed exclusively by CR cells.

$\leftarrow$

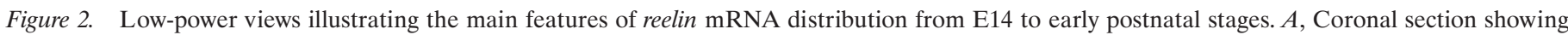

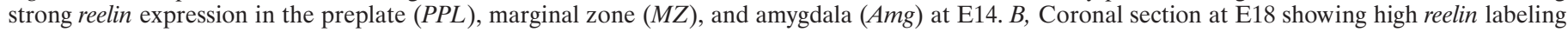

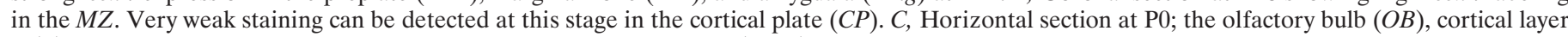

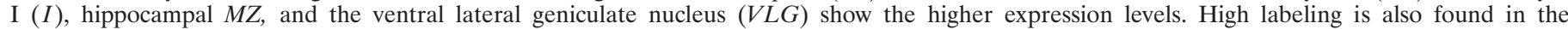

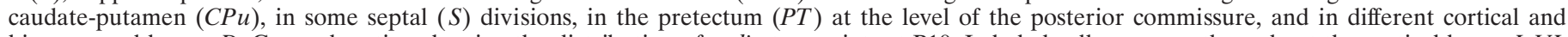

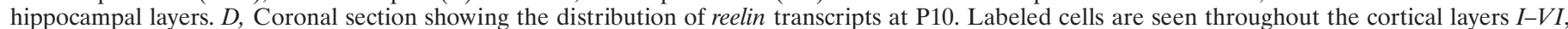

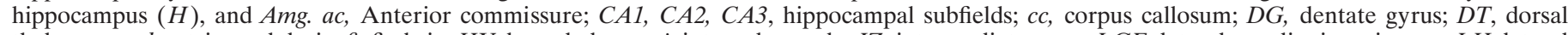

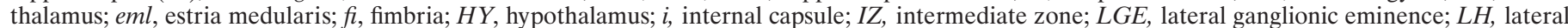

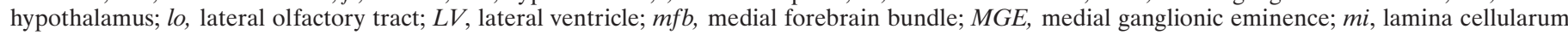

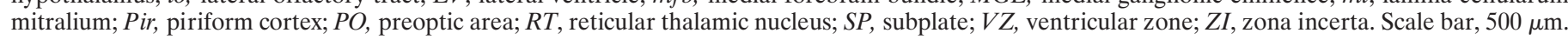


Table 2. reelin mRNA distribution in the murine forebrain at E14-adult stages

\begin{tabular}{|c|c|c|c|c|c|c|c|c|c|}
\hline & E14 & E16 & E18 & $\mathrm{P} 0$ & P5 & $\mathrm{P} 10$ & $\mathrm{P} 15$ & $\mathrm{P} 21$ & $\mathrm{AD}$ \\
\hline \multicolumn{10}{|l|}{ Telencephalon } \\
\hline \multicolumn{10}{|l|}{ Olfactory bulb } \\
\hline Mitral cells & +++ & ++++ & ++++ & ++++ & +++ & ++ & ++ & ++ & + \\
\hline External granular cells & - & - & - & - & ++ & ++ & ++ & ++ & + \\
\hline \multicolumn{10}{|l|}{ Neocortex } \\
\hline Layer I & +++ & ++++ & ++++ & ++++ & +++ & + & + & + & + \\
\hline Layers II-IV & - & - & - & - & + & ++ & + & + & + \\
\hline Layers V-VI & - & - & + & ++ & +++ & ++ & + & + & + \\
\hline \multicolumn{10}{|l|}{ Palleocortex } \\
\hline Layer I & +++ & +++ & +++ & +++ & ++ & ++ & + & + & + \\
\hline Layer II & - & + & + & +++ & +++ & ++ & ++ & ++ & + \\
\hline Rest of layers & - & - & + & ++ & +++ & ++ & + & + & + \\
\hline \multicolumn{10}{|l|}{ Hippocampus } \\
\hline Stratum lacunosum-moleculare & +++ & ++++ & ++++ & ++++ & +++ & ++ & ++ & + & + \\
\hline Stratum oriens & - & + & ++ & +++ & +++ & ++ & + & + & + \\
\hline Stratum radiatus & - & + & ++ & +++ & +++ & ++ & + & + & + \\
\hline Hilus & - & - & - & - & +++ & ++ & ++ & + & + \\
\hline \multicolumn{10}{|l|}{ Basal forebrain } \\
\hline Medial septum/diagonal band & + & + & + & ++ & ++ & ++ & + & + & + \\
\hline Lateral septum & - & - & + & ++ & + & + & + & - & - \\
\hline Bed nucleus/stria terminalis & + & + & + & + & + & + & + & + & - \\
\hline Olfactory tubercle/taenia tecta & +++ & +++ & +++ & +++ & ++ & + & + & + & - \\
\hline Caudate-putamen & + & ++ & +++ & +++ & ++ & + & + & + & - \\
\hline Nucleus acumbens & - & + & +++ & +++ & ++ & - & - & - & - \\
\hline Amygdala & + & + & ++ & ++ & ++ & ++ & ++ & ++ & + \\
\hline Substantia innominata & + & + & + & ++ & + & + & + & + & - \\
\hline Entopeduncular area/internal capsule & ++ & ++ & ++ & ++ & ++ & + & + & + & - \\
\hline \multicolumn{10}{|l|}{ Hypothalamus } \\
\hline Anterior nucleus & ++ & ++ & ++ & + & + & + & + & - & - \\
\hline Lateral part & ++ & ++ & ++ & ++ & ++ & + & - & - & - \\
\hline Paraventricular nucleus & ++ & ++ & +++ & +++ & ++ & + & + & + & - \\
\hline Supraoptic area & ++ & ++ & ++ & ++ & + & + & + & + & - \\
\hline \multicolumn{10}{|l|}{ Diencephalon } \\
\hline \multicolumn{10}{|l|}{ Epithalamus } \\
\hline Paraventricular nucleus & ++ & + & + & + & + & - & - & - & - \\
\hline Habenula & + & ++ & ++ & ++ & + & + & + & + & - \\
\hline \multicolumn{10}{|l|}{ Ventral thalamus } \\
\hline Ventral lateral geniculate nucleus & ++ & ++ & +++ & +++ & +++ & ++ & + & + & - \\
\hline Reticular nucleus & ++ & + & - & - & - & - & - & - & - \\
\hline Zona incerta & ++ & + & + & + & + & + & - & - & - \\
\hline External medulary lamina & +++ & +++ & +++ & +++ & ++ & + & - & - & - \\
\hline \multicolumn{10}{|l|}{ Pretectum } \\
\hline Posterior commisure nuclei & ++ & ++ & +++ & +++ & ++ & ++ & + & + & + \\
\hline Anterior and olivary nuclei & ++ & ++ & ++ & ++ & ++ & ++ & + & + & + \\
\hline
\end{tabular}

Low $(+)$, moderate $(++)$, high $(+++)$, and very high $(++++)$ levels of reelin expression are shown. No detectable levels of expression are also indicated $(-)$.

\section{reelin expression in the developing marginal zone of the hippocampus}

At E12-E14 the hippocampal region displayed strong reelin expression (Figs. 1D, 2A). At these stages, when the hippocampal plate (prospective pyramidal layer) (Soriano et al., 1994) has still not emerged, labeled neurons were seen in the outermost layer. At E16, when the typical layering of the hippocampus and the primordium of the dentate gyrus are visible, heavily labeled neurons were abundant in the outer marginal zone (prospective stratum lacunosum-moleculare) just below the hippocampal fissure. In addition, a second population of weakly stained cells was present in other hippocampal layers, such as the inner marginal zone, and in the subplate (prospective stratum radiatum and stratum oriens, respectively).

At E18-P0 and at early postnatal stages, the pattern of reelin expression remained the same, with the following exceptions. First, as development of the dentate gyrus proceeded, increased numbers of intense reelin-positive neurons were detected in the outer molecular layer; indeed, at P5-P10, when the late-formed dentate infrapyramidal blade emerges, a band of reelin-positive cells appeared in the outer molecular layer of this blade below the pia. Second, the number of reelin-expressing neurons in the stra- 


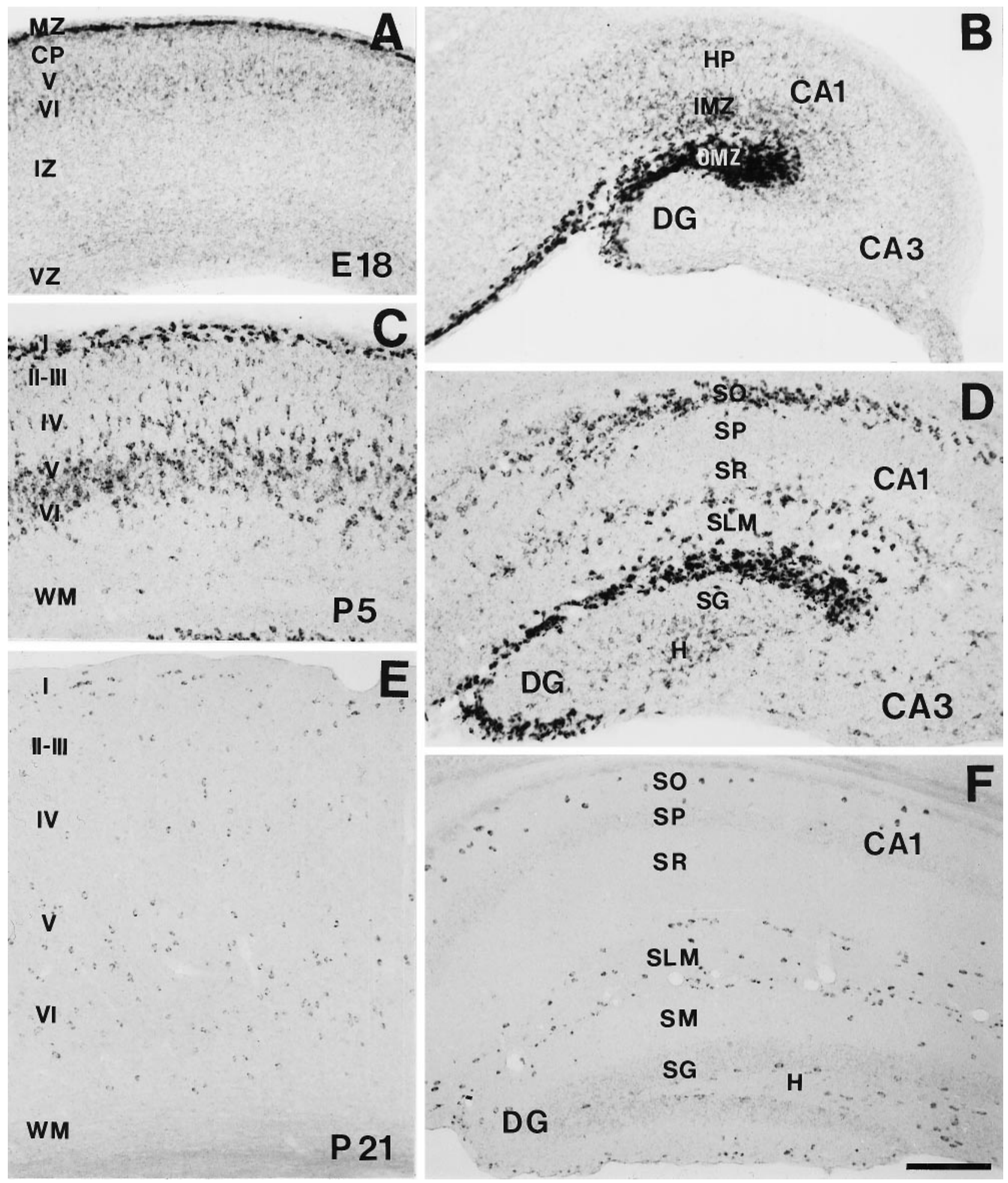

Figure 3. Photomicrographs illustrating the pattern of reelin expression in the neocortex and hippocampus from late embryonic stages to P21. A, In the neocortex at E18, reelin expression is maximal in the marginal zone $(M Z)$; scattered positive cells are also seen in layers $V$ and $V I$. B, In the E18 hippocampus, the highest expression levels correspond to the outer marginal zone (OMZ), but positive cells are also seen in the inner marginal zone $(I M Z)$ and around the hippocampal plate $(H P)$. C, At P5, reelin expression increased in the neocortex, with labeled cells mainly localized in cortical layers $I, V$, and $V I$. $D$, In the $\mathrm{P} 5$ hippocampus, positive cells are very abundant near the hippocampal fissure [stratum lacunosum-moleculare $(S L M)$ ], stratum oriens $(S O)$, and hilus $(H)$. E, $F$, At P21 reelin expression shows a dramatic decrease in both the neocortex $(E)$ and the hippocampus $(F)$. $C A 1, C A 3$, Hippocampal subfields; $C P$, cortical plate; $D C$, dentate gyrus; $I Z$, intermediate zone; $S G$, stratum granulare; $S P$, stratum pyramidale; $S R$, stratum radiatum; $V Z$, ventricular zone; $W M$, white matter. Scale bar, $200 \mu \mathrm{m}$. 


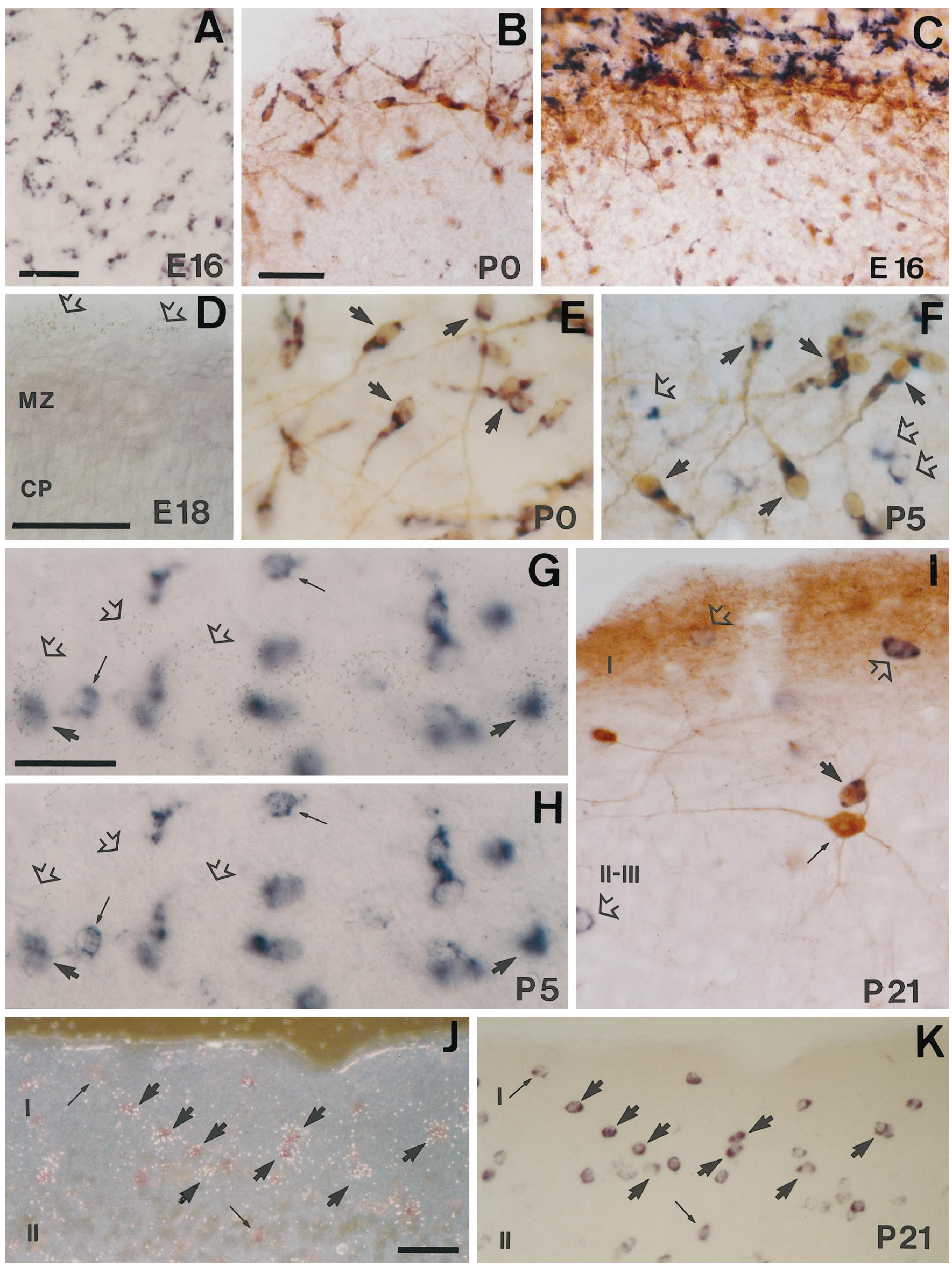


tum radiatum and oriens increased at perinatal stages, and labeled cells were also observed in the dentate hilar region from $\mathrm{P} 0$ onward (Figs. $2 B-D, 3 B, D$ ).

Double-labeling analyses with calretinin antibodies revealed a complex pattern of colocalization in the prenatal hippocampus. At E14 three layers of cells were distinguished in the preplate: an outer band formed by cells solely expressing reelin mRNA, a middle layer composed by neurons co-expressing reelin and calretinin, and an inner band of neurons positive only for calretinin (see Fig. 5D). These reelin-negative/calretinin-positive cells might correspond to calretinin-immunoreactive neurons other than $\mathrm{CR}$ cells (e.g., subplate or CA3 pyramidal neurons). At E16-P0, in contrast, there was complete colocalization of reelin and calretinin in the outer marginal zone, with double-labeled neurons having horizontal cell bodies and dendrites and corresponding to CR cells (see Fig. 5E) (Soriano et al., 1994; Del Río et al., 1995, 1996).

Sections from E18 embryos simultaneously hybridized with reelin and GAD65/67 riboprobes revealed faint GAD65/67positive neurons in the stratum radiatum and stratum oriens, but not in the outer marginal zone. Consistent with the nonisotopic hybridization observations (see above), the GAD65/67-positive neurons in the stratum radiatum and stratum oriens displayed weak autoradiographic signals corresponding to reelin mRNA (see Fig. $5 A-C$ ). Some of these reelin-positive neurons were immunoreactive for calbindin and calretinin, which label subpopulations of nonpyramidal neurons in these layers (see below). Taken together, these findings show that reelin is highly expressed in GAD65/67-negative CR cells of the hippocampus and that, as in the neocortex, the onset of reelin expression in these neurons precedes that of calretinin. In addition, some GAD65/67-positive neurons located in the prospective radiatum and oriens strata express low levels of reelin from E16 onward.

\section{Expression of reelin mRNA in layer I and stratum lacunosum-moleculare at postnatal and adult stages} Neocortex

At $\mathrm{P} 5$, reelin was still heavily expressed in many cells in layer I (Fig. 3C). In contrast to previous ages, double-labeling studies revealed a complex pattern of expression in which reelin/ calretinin-positive neurons constituted about half the reelin population of layer I (104 of 181 cells, 57\%), and the remaining neurons expressed only reelin (Fig. $4 F$ ). Furthermore, doublehybridization analyses revealed expression of reelin in both GAD65/67-positive and -negative neurons (Fig. 4G,H). These observations indicate that at P5, the earliest stage of CR cell disappearance (Derer and Derer, 1990; Del Rio et al., 1995,
1996), reelin mRNAs are expressed both in CR cells and in a subpopulation of GABAergic neurons in layer I.

At subsequent ages (P10, P15, P21, and adult) reelin signals decreased steadily, although substantial numbers of faintly labeled neurons were observed in layer I (Fig. 3E). Studies with calretinin antibodies showed progressively fewer double-labeled neurons at these postnatal stages, with most neurons expressing only reelin. In contrast, at $\mathrm{P} 21$ and adult stages, all reelinexpressing neurons in layer I also co-expressed GAD65/67 mRNAs (Fig. 4I-K). These findings indicate that reelin-positive neurons in the late postnatal and adult layer I belong to the GABAergic neurons intrinsic to this layer.

\section{Hippocampus}

Similar, but delayed, changes in the pattern of reelin expression were seen in the molecular layer/stratum lacunosum-moleculare of the hippocampus at postnatal stages. Thus, reelin expression was still high at P5-P15 in hippocampal CR cells, whereas at P21 there was a marked reduction both in the intensity of reelin labeling and in the number of double-labeled calretinin-positive neurons in the outer molecular layer/stratum lacunosummoleculare (Figs. 3D,F, 5F,K). Most such double-labeled neurons, presumably CR cells, persisted in the adult hippocampus, displaying small sizes.

As in the neocortex, reelin expression was also detected from P5 onward in calretinin-negative, non-CR cells in the molecular layer/stratum lacunosum-moleculare. These cells expressed GAD65/67 mRNAs at both postnatal and adult stages (Fig. 5G$J)$. In the adult, reelin/GAD65/67-positive neurons represented $\sim 25 \%$ of the population of reelin-expressing cells in the molecular layer/stratum lacunosum-moleculare (34 of 138 cells). These findings show that from P5 onward reelin transcripts are expressed in a population of GABAergic neurons present in the derivatives of the hippocampal marginal zone and that, in contrast to the neocortex, reelin expression persists in a small subpopulation of CR cells that appear to survive to adult stages.

\section{Expression of reelin mRNA in the derivatives of the cortical plate in the developing and adult cerebral cortex}

\section{Neocortex}

A band of reelin-expressing neurons emerged in layers V and VI of the neocortex at E18 (Fig. 3A). This band was formed by weakly labeled neurons that were widely distributed throughout the rostrocaudal and mediolateral axes of the cerebral cortex. At $\mathrm{P} 0-\mathrm{P} 5$, reelin expression became more prominent in layers $\mathrm{VI}-\mathrm{V}$,

\section{$\leftarrow$}

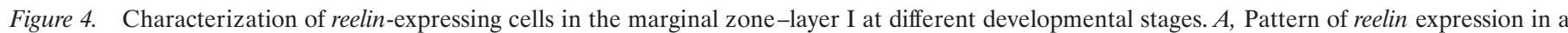

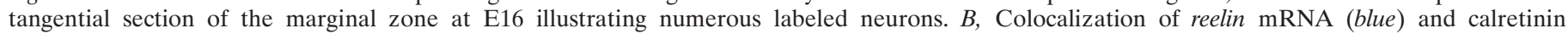

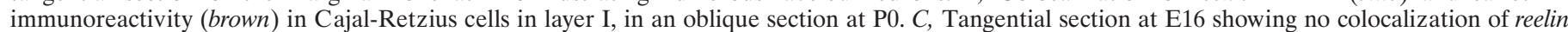

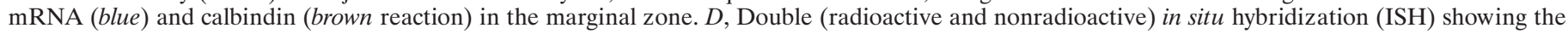

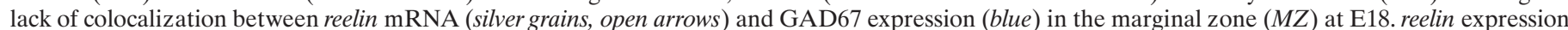

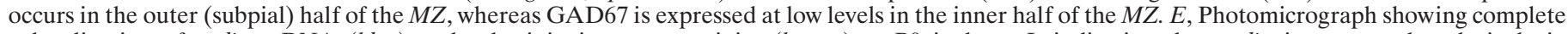

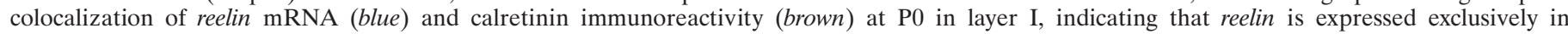

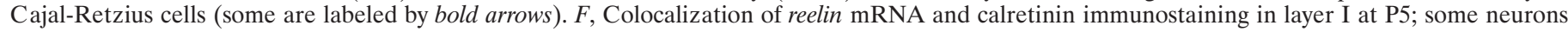

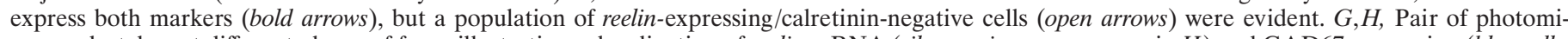

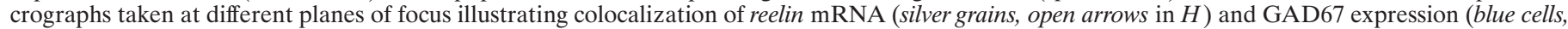

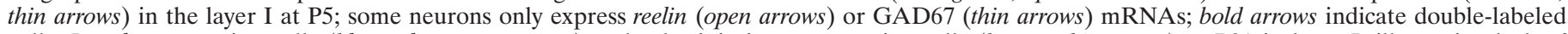

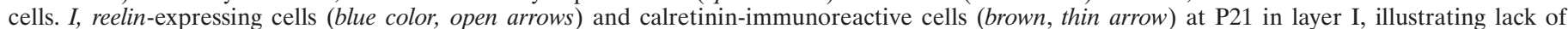

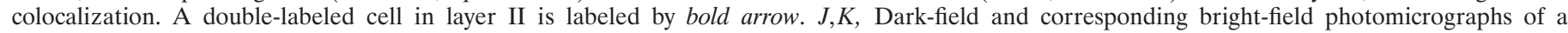

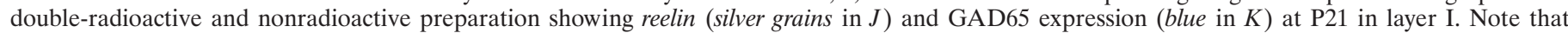

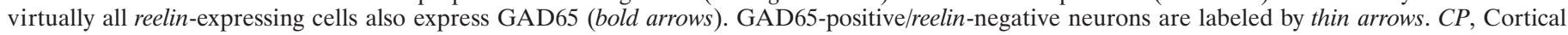
plate; SP, subplate; I, II-III, cortical layers. Scale bars, $50 \mu \mathrm{m}$. 


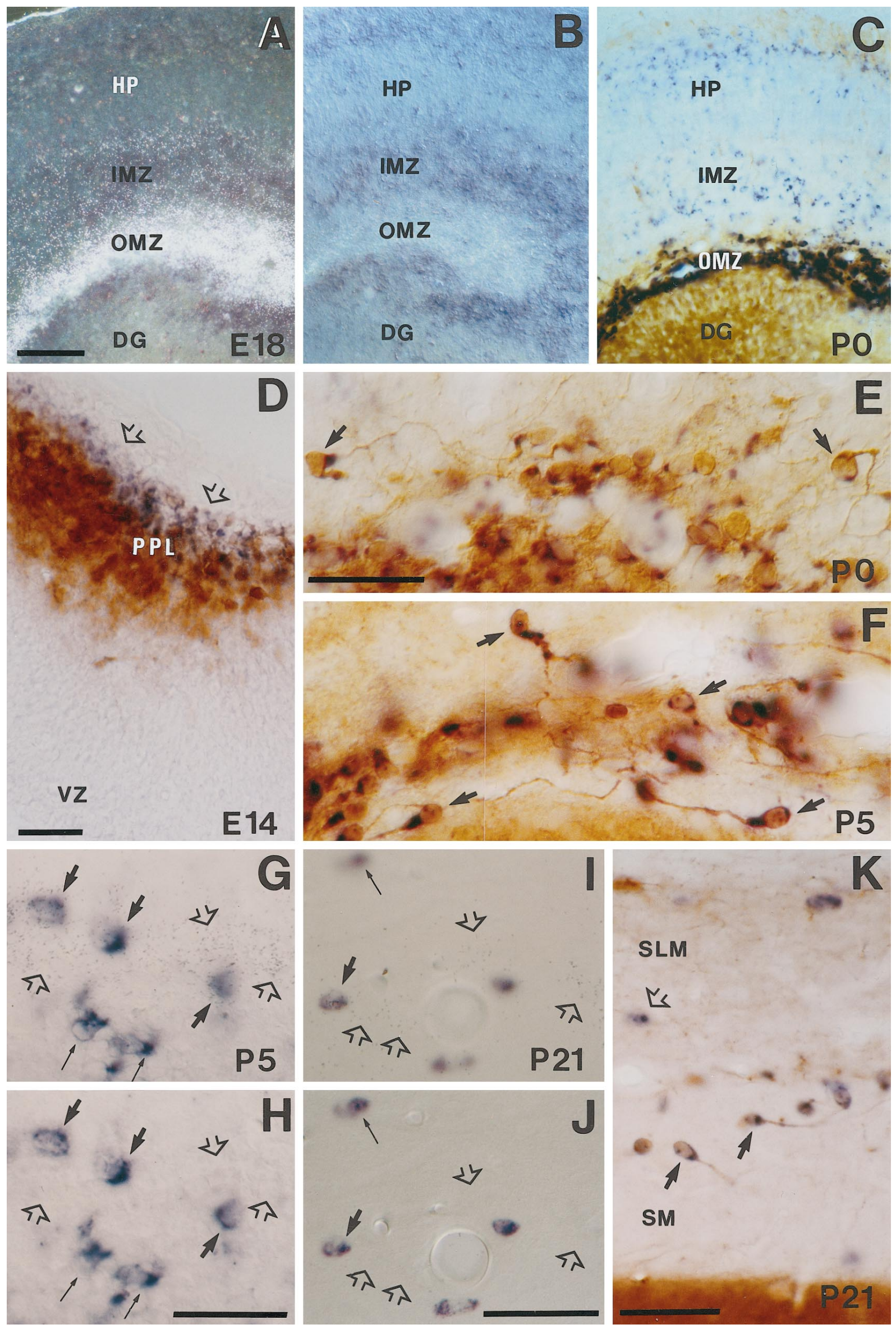


and a few positive neurons were also seen in the dense cortical plate (layers II-IV) (Figs. 2C, 3C). In the early postnatal mouse, calbindin and calretinin antibodies label subpopulations of both pyramidal cells in layers V-VI and nonpyramidal neurons throughout the cortex (Del Rio et al., 1995, 1996). Both neuronal groups, however, could be distinguished on the basis of their characteristic perikaryal shapes and dendritic orientations. Colocalization studies showed that at $\mathrm{P} 0-\mathrm{P} 5$, reelin transcripts were expressed in subsets of calretinin- and calbindin-immunoreactive neurons exhibiting multipolar shapes and corresponding to nonpyramidal neurons. There were also many immunoreactive nonpyramidal neurons that did not express the reelin message. In contrast, reelin mRNA was never detected in immunoreactive pyramidal neurons (Fig. $6 A-C$ ), which is consistent with the finding that virtually all reelin-positive cells in layers VI-II expressed GAD65/67 at P5 (data not shown).

Subsequently (P10, P15, P21, and adult) there was a progressive decrease in the levels of reelin expression. However, many positive neurons were present throughout the cortical layers, with a higher density in layers VI-V and I, in P21, and in adult sections (Fig. $3 E$ ). No remarkable differences were noticed between different neocortical areas in the adult cerebral cortex. Colocalization analyses showed that virtually every reelin-positive neuron present in layers VI-II also expressed GAD65/67 mRNA, confirming that reelin transcripts in the adult neocortex are expressed in subsets of GABAergic interneurons (Figs. 4J,K, 6G,H).

To determine whether reelin was expressed by particular classes of nonpyramidal neurons in the adult neocortex, a detailed colocalization analysis was performed using antibodies against the calcium-binding proteins parvalbumin, calretinin, and calbindin, as well as against the neuropeptides NPY, somatostatin, VIP, and CCK (Figs. 6D-F, 7). These antibody markers label distinct, although partially overlapping, subpopulations of cortical interneurons (de Felipe, 1993; Freund and Buzzáki, 1996; Cauli et al., 1997). Studies were focused on the primary somatosensory barrel cortex, but similar patterns of colocalization were observed in other cortical areas. No reelin transcripts were detected either in the granule cells of layer IV or in the pyramidal cells of layers II-III, which are weakly stained with calbindin antibodies. reelin was expressed only very rarely in parvalbumin-, cholecystokinin-, or VIP-positive interneurons (e.g., 2 of 710 parvalbumin-positive cells). In contrast, reelin-positive cells showed variable degrees of colocalization with the subpopulations of calretinin-, calbindin-, NPY-, and somatostatin-immunoreactive neurons. Although reelin and calretinin or NPY colocalized mainly in the supragranular layers, most double-labeled calbindin-positive neurons were located in layers V and VI (Fig. 7).

reelin mRNA did not colocalize with the entire subpopulation of immunoreactive neurons for any antibody marker. Thus, reelin was found in low percentages $(<20 \%)$ of calbindin- and calretinin-immunoreactive neurons, whereas about half the NPYand somatostatin-positive neurons co-expressed reelin message in layers II-III and IV (Fig. 7). In no cortical layer did the sum of double-labeled neurons account for the total number of reelinpositive neurons. For instance, in layers II-III and IV, in total only $\sim 80 \%$ of the reelin-positive neurons were double-labeled with the different antibody markers. Taken together, these observations demonstrate that reelin transcripts are expressed in a heterogeneous population of cortical nonpyramidal neurons.

\section{Hippocampus}

At P5-P15 there were many weakly labeled reelin-positive neurons in the hippocampus outside the molecular layer/stratum lacunosum-moleculare that persisted to P21-adult stages. These neurons were distributed throughout the layers, but they were more abundant in the hilus and stratum oriens (Fig. $3 F$ ). As in the neocortex, these neurons co-expressed GAD65/67 transcripts (data not shown), indicating that they are GABAergic nonpyramidal interneurons. reelin transcripts were not detected in the principal pyramidal and granule cells of the hippocampus at any postnatal stage or in the adult.

Double-labeling analyses performed on hippocampal sections from P21 and adult mice showed that, similar to the neocortex, reelin was rarely expressed in the subpopulations of parvalbumin-, CCK-, and VIP-immunoreactive neurons (1-6\% colocalization). In contrast, variable numbers of calretinin- (104 of 140, 58\%), calbindin- $(25$ of $185,14 \%)$, somatostatin- (138 of 185, 75\%), and NPY- (20 of 66, 30\%) immunoreactive neurons expressed reelin (Figs. 6I, 8). These double-labeled neurons were scattered throughout the hippocampal layers but were especially abundant in the stratum oriens and in the hilus. In these layers most somatostatin-immunoreactive neurons displayed reelin signals. These observations indicate that in both the developing and adult hippocampus, reelin is expressed in distinct subpopulations of GABAergic nonpyramidal neurons.

\section{reelin expression in the developing and adult piriform and entorhinal cortices}

The developmental pattern of reelin expression in the piriform and entorhinal areas (paleocortex) paralleled, to a large extent,

\section{$\longleftarrow$}

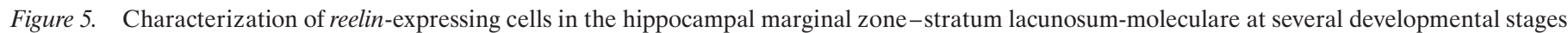

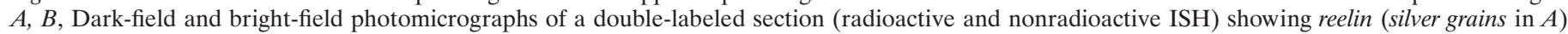

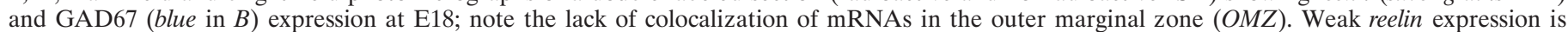

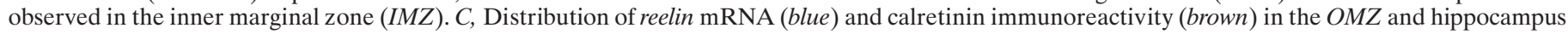

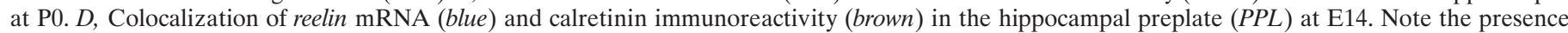

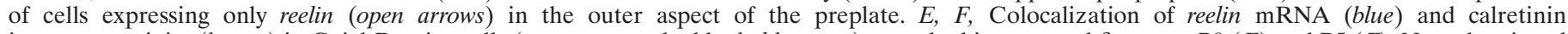

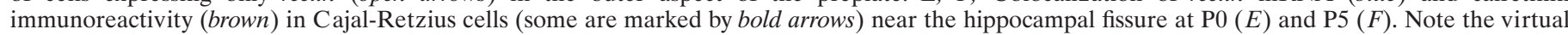

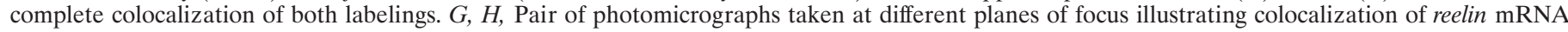

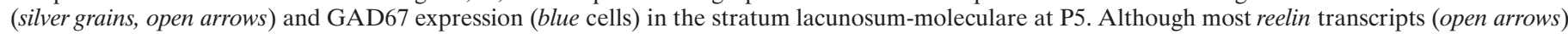

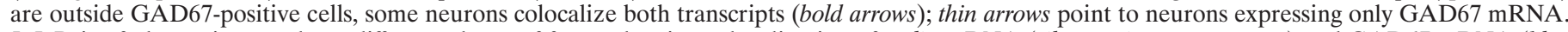

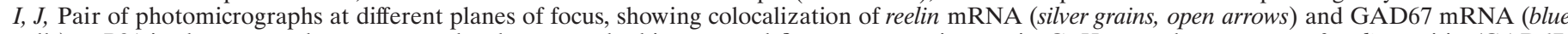

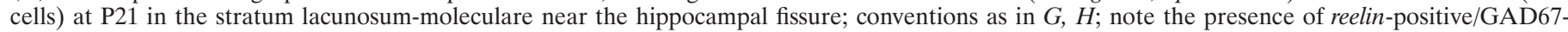

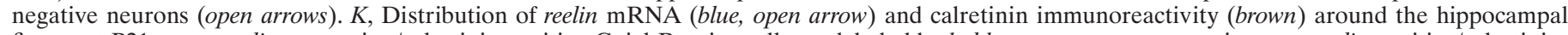

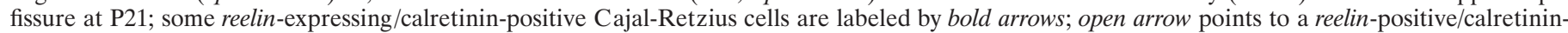

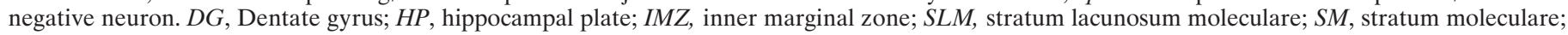
$V Z$, ventricular zone. Scale bars: $A-C, 100 \mu \mathrm{m} ; D-K, 50 \mu \mathrm{m}$. 

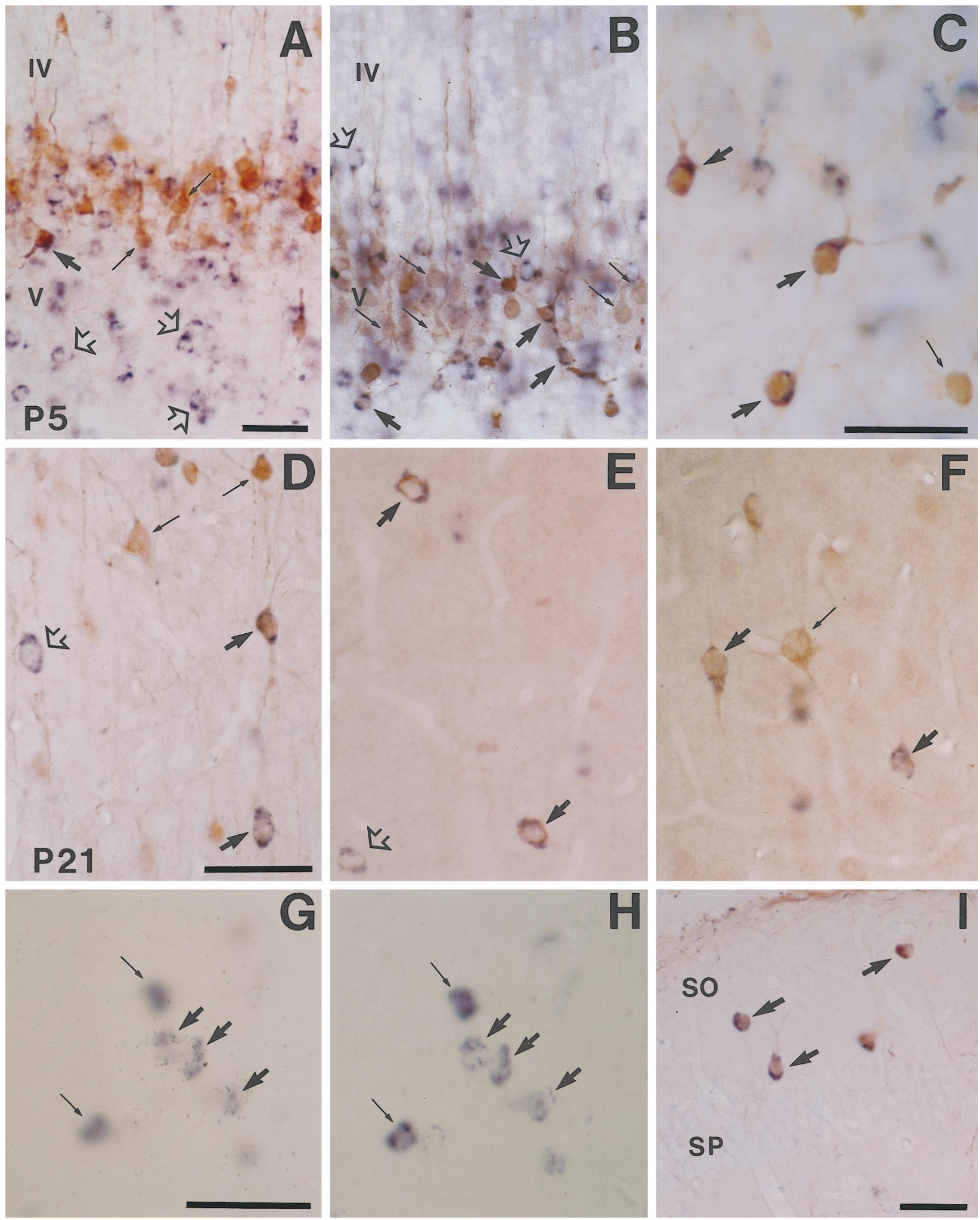

Figure 6. reelin-expressing cells in the derivatives of the cortical plate and in the adult cerebral cortex and hippocampus are GABAergic nonpyramidal neurons. $A, B$, Distribution of reelin mRNA (blue, open arrows) and calretinin immunoreactivity (brown in $A$ ) or calbindin immunoreactivity (brown in $B$ ) in cortical layers IV and V of the neocortex at P5; double-labeled neurons are marked by bold arrows; calretinin-positive pyramidal neurons (thin arrows) do not express reelin transcripts. $B$, $C$, reelin-positive/calbindin-positive neurons in layer $\mathrm{V}$ at $\mathrm{P} 5$ display nonpyramidal shapes (bold arrows). A calbindin-immunoreactive neuron is labeled by a thin arrow. $D-F$, Photomicrographs of the layer II-III of the neocortex at P21 showing reelin expression (blue color, open arrows) and immunostaining (brown, thin arrows) for calretinin $(D)$, neuropeptide Y $(E)$, and somatostatin $(F)$; double-labeled nonpyramidal neurons are indicated by bold arrows. $G, H$, Pair of photomicrographs taken at different planes of focus showing colocalization of reelin mRNA (silver grains in G, open arrows) and GAD67 mRNA (blue cells) at P21 in layer V of the neocortex; bold arrows point to double-labeled cells. I, Colocalization of reelin mRNA (blue) and calretinin immunoreactivity (brown) in the hippocampus at P21. Double-labeled neurons in the stratum oriens are labeled by bold arrows. $S O$, Stratum oriens; $S P$, stratum pyramidale; $I V$, $V$, cortical layers. Scale bars, $50 \mu \mathrm{m}$. 
REELIN

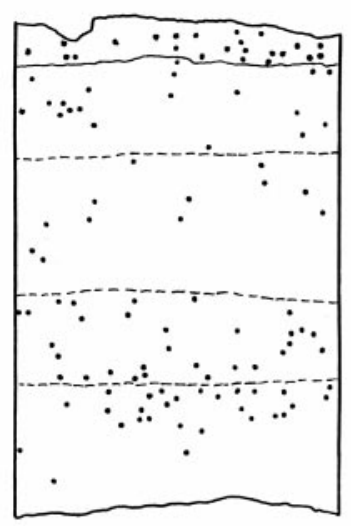

- Reelin
CALBINDIN

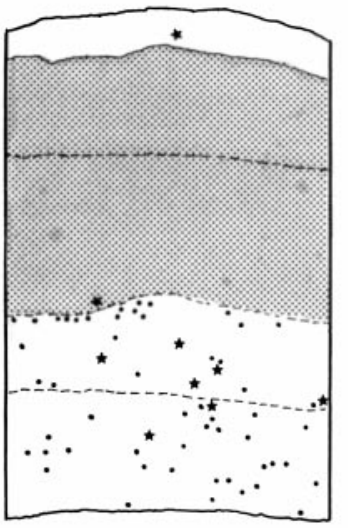

- Calbindin

$\star$ Reelin + Calbindin
CALRETININ

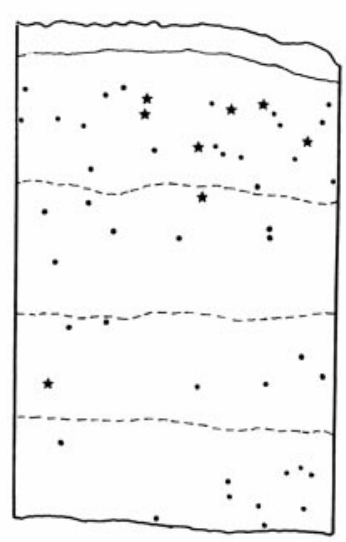

- Calretinin

$\star$ Reelin + Calretinin
NPY

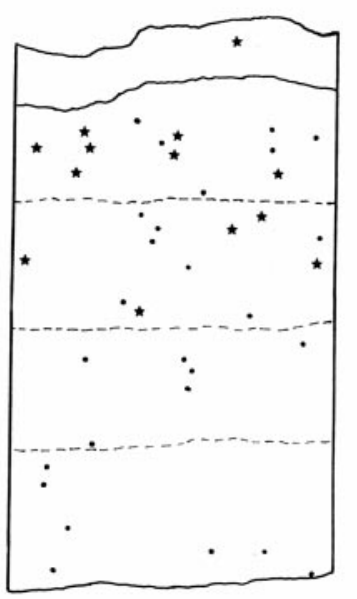

- NPY

$\star$ Reelin + NPY
SOMATOSTATIN

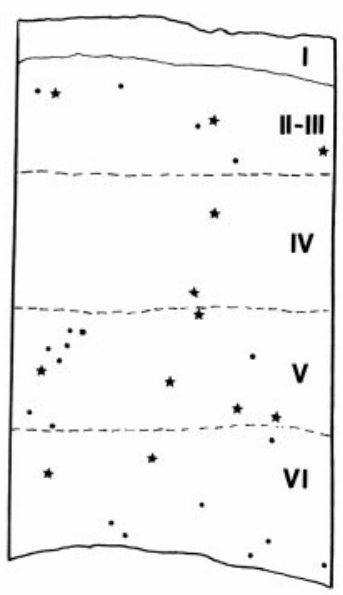

- Somatostatin

$\star$ Reelin + Somatostatin
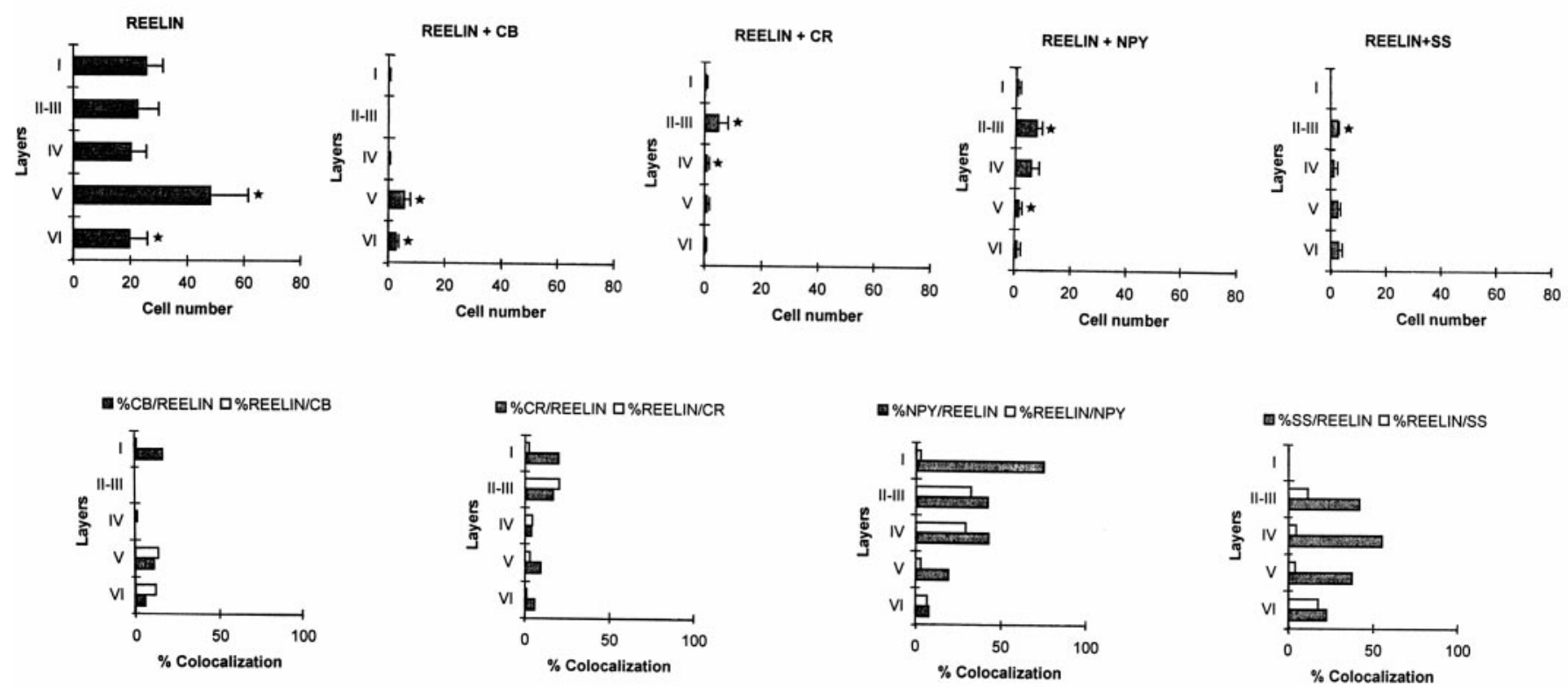

Figure 7. Camera lucida drawings (top) and histograms showing the distribution of reelin-expressing cells, and the percentages of colocalization with several calcium-binding proteins and neuropeptides, in different layers of the adult somatosensory neocortex. Data in the middle are the number of positive cells found in each single layer (average SD). Statistically significant differences between layers are indicated $\left({ }^{*} p=0.01\right)$. Histograms at bottom show percentages of colocalization within different cortical layers. Scale bar, $300 \mu \mathrm{m}$.

that in the neocortex, in both the temporal and laminar patterns of expression (Tables 1, 2). Thus, during embryogenesis, reelin mRNA was detected mainly in the marginal zone-layer I, where immunocytochemical analyses with calretinin antibodies confirmed expression of reelin in CR cells (data not shown). From E16 onward, reelin was expressed in neurons scattered throughout the cortical layers, which were still present in the adult. As in the adjacent neocortex, these neurons expressed markers typical for cortical interneurons, including GAD65/67 mRNAs and calciumbinding proteins (data not shown).

A particular feature of these cortical regions was the expression of reelin mRNA in a narrow band of neurons located below layer I, corresponding to layer II. reelin expression in these neurons started at E16, was maximal at early postnatal stages, and persisted in the adult brain (Figs. $2 B, C, 9 G$ ). At no time did these reelin-positive neurons express GAD65/67, nor were they positive 
REELIN

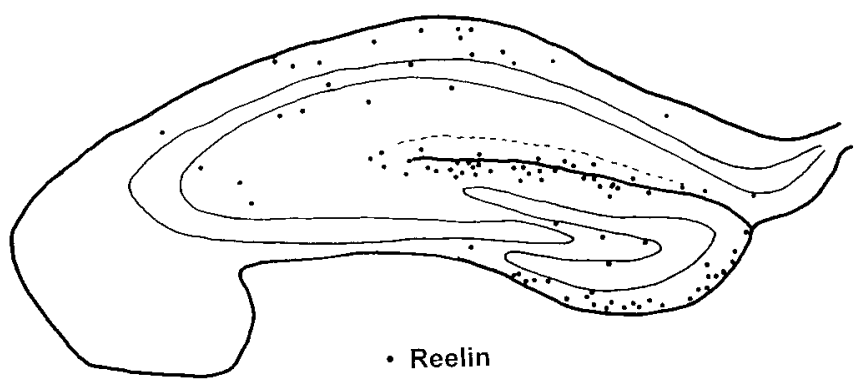

CALBINDIN

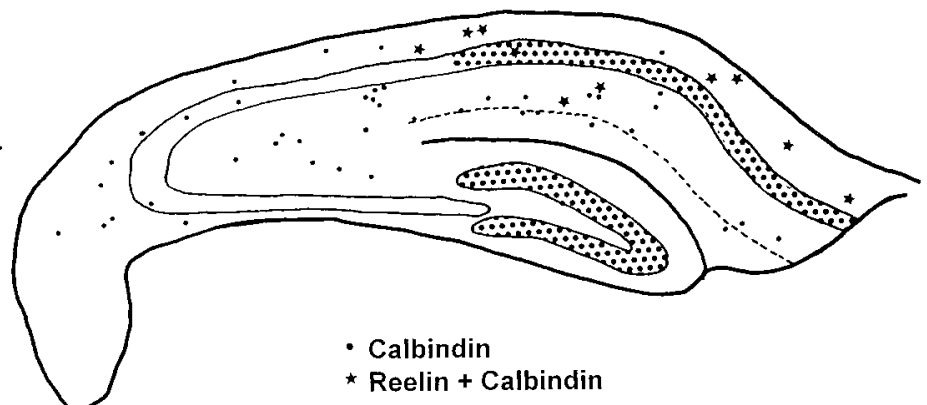

CALRETININ

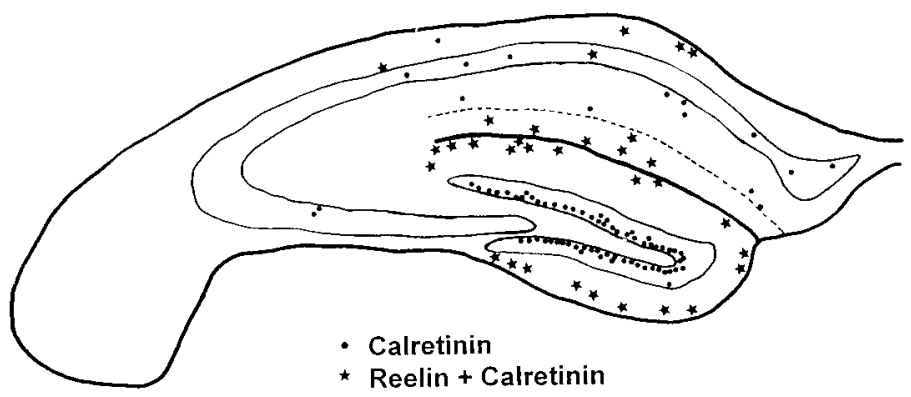

SOMATOSTATIN

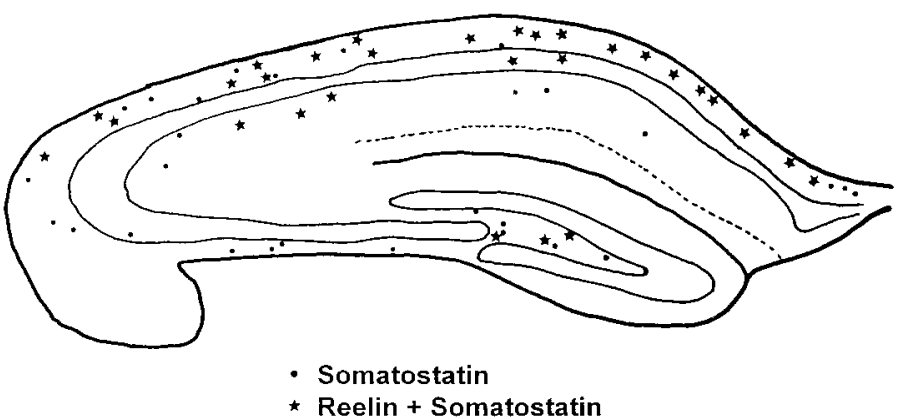

Figure 8. Camera lucida drawings of hippocampal sections showing the distribution of reelin-expressing cells in the adult, and colocalization with several calcium-binding proteins and neuropeptides. Scale bar, $350 \mu \mathrm{m}$.

for any of the antibody markers that label cortical interneurons. We conclude that the pyramidal neurons located in layer II of the piriform and entorhinal cortices express reelin transcripts in both the developing and adult brain, in addition to GABAergic interneurons.

\section{Pattern of reelin expression in the olfactory bulb, basal forebrain, and hypothalamus}

\section{Olfactory bulb}

The olfactory bulb was a site of prominent reelin expression. From E12 onward, reelin mRNA was highly expressed in a circular band of cells, which corresponded to the mitral cell layer (Fig. $9 A-C)$. reelin was expressed in mitral cells at high levels during the prenatal period and the first postnatal week, and it decreased thereafter to adult levels. Double-labeling experiments confirmed that reelin-positive cells in this layer did not express GAD65/67 mRNA (Fig. 9D-F) and that most of them were immunoreactive for calretinin, as corresponds to the mitral cells (data not shown).

A second site of reelin expression appeared in the olfactory bulb from P5 onward, at the innermost part of the glomerular layer (lamina granularis externa) (Fig. 9B,C). Here, reelin expression was found in a subset of neurons that did not express GAD65/67 mRNA (Fig. 9E,F) or display calcium-binding protein immunostaining. In the adult olfactory bulb, reelin transcripts were still detectable, but at lower levels, in mitral neurons and in a subset of periglomerular neurons located in the area just opposite the mitral cell layer (lamina granularis externa). reelin was not expressed at any stage in the olfactory subventricular zone or in the rostral migratory stream and the caudal subventricular zone, which generate olfactory interneurons throughout postnatal and adult life (Luskin, 1993; Lois and Alvarez-Buylla, 1994; Jankovski and Sotelo, 1996; Lois et al., 1996).

\section{Basal forebrain}

At E11-E12, heavily labeled reelin-positive cells were located throughout the surface of the ventral telencephalon, including the prospective septal area (Fig. 1D,E). From E14 onward, reelin expression increased steadily in many basal forebrain areas to peak at E18-P0, decreasing thereafter by P5-P10 (Fig. 2A-D). Prominent sites of expression included the prospective caudateputamen, the amygdaloid complex, the medial septum/diagonal band complex, and the taenia tecta/olfactory tubercle. reelin hybridization signals were found to be unevenly distributed in the caudate-putamen, which showed patches of higher expression, especially near the subcortical white matter. reelin-expressing cells were also found transiently in many other basal forebrain areas such as the lateral septum, the accumbens nucleus, the preoptic area, the bed nucleus and stria terminalis, and the entopeduncular area/internal capsule. In contrast, other regions, such as the globus pallidus, never displayed hybridization signals. Despite the widespread distribution of reelin message during development, only a few neurons exhibiting weak reelin expression were detected in the adult in the medial septum/diagonal band complex and in the amygdaloid region. 


\section{Hypothalamus}

From E14 onward, reelin expression steadily increased in many hypothalamic structures. The paraventricular hypothalamic nucleus was a site of prominent reelin expression, but hybridization signals were also found in the anterior, lateral, and supraoptic hypothalamic divisions. reelin expression in these regions peaked at birth and decreased from P5 on until the adult stage, when it was no longer detectable (Figs. $2 B, D, 10 C, D$ ).

\section{reelin mRNA expression in the developing diencephalon}

In the epithalamus, the paraventricular epithalamic nucleus and the medial habenular complex showed medium levels of reelin expression from early stages (E12) until P5 and P21, respectively (Table 2). The dorsal thalamus remained largely devoid of reelin expression at any time.

At E12-E14 in the ventral thalamus, prominent reelin expression was found in the reticular nucleus, zona incerta, zona limitans intrathalamica, and ventral lateral geniculate nucleus (Figs. $1 B, F, 10 A, B)$. As development proceeded, reelin expression in the ventral thalamus became mostly restricted to the zona limitans intrathalamica (future external medullary lamina) and the ventral lateral geniculate nucleus, reaching a peak between E18 and P5. Low levels of expression were also found in the reticular nucleus and zona incerta up to E16 and P10, respectively. reelin expression in the ventral thalamus decreased from P5 onward, so that by P21 only a few positive cells could be seen in the ventral lateral geniculate nucleus. No reelin transcripts were detected in the adult ventral thalamus (Figs. $2 B-D, 10 C, D$ ).

In the pretectum, the anterior and olivary pretectal nuclei and the nuclei related to the posterior commissure showed prominent reelin expression during embryonic and early postnatal development (Figs. 2C, 10E). From P10 onward, expression decreased in these regions, and only a few faintly labeled reelin-expressing cells were seen in the adult.

\section{DISCUSSION}

\section{Early reelin mRNA expression and regionalization of the prosencephalon}

The domains of reelin expression in the diencephalon of early embryos are coincidental with three neuromeric boundaries as proposed in the prosomeric model of forebrain regionalization (Puelles and Rubenstein, 1993). The onset of reelin expression in these boundaries (as early as E10) occurs at the time when the precocious patterns of neuronal regionalization and the earliest neural connections are being formed in the diencephalon, which may suggest a role for Reelin in these processes.

It has been suggested that neuromeric boundaries ultimately provide positional information required for the migration of neurons and for the navigation of their axons, acting either as barriers or as regions of preferential growth (Wilson et al., 1993; Chedotal et al., 1995; Mastick and Easter, 1996; Kitamura et al., 1997; Mastick et al., 1997). In fact, some regulatory genes such as pax 6 regulate the expression of specific cell adhesion molecules and extracellular proteins such as L1 and R-cadherin (Chalepakis et al., 1994; Stoykova et al., 1997). Thus, despite the apparent lack of gross morphological abnormalities in the diencephalon of adult reeler mice (Caviness et al., 1988), further analyses in mutant embryos are needed to determine the contribution of Reelin to early brain regionalization, given the function of this protein in axonal growth (see below).

\section{reelin mRNA expression in Cajal-Retzius cells}

Our colocalization data show that, at prenatal stages, reelin expression in layer I is restricted to CR cells. From P5 onward, reelin expression decreases in calretinin-positive CR cells, at the same time that GAD65/67-positive neurons express reelin. There are at least two possible explanations for these findings. (1) CR cells disappear by cell death as reelin expression begins in GAD65/67positive neurons, and (2) CR cells lose calretinin expression and adopt a new GABAergic phenotype. The timing of reelin loss in CR cells (P5-P15) is consistent with the period of CR cell death (Derer and Derer, 1992; Del Río et al., 1995, 1996). Also, if the GABAergic neurons of the adult layer I were transformed CR cells, they should have been born at early stages of corticogenesis (E10-E11 in the mouse) because CR cells are the earliest cortical neurons to become postmitotic (Derer and Derer, 1992; Del Río et al., 1995). However, the GABAergic neurons of layer I are generated steadily throughout the period of neurogenesis (E11E17 in the mouse) (Fairén et al., 1986). Thus, these data support the view that most reelin-positive CR cells disappear by cell death and that GABAergic interneurons express reelin postnatally.

A similar process of disappearance, although less dramatic, may hold true for CR cells in the hippocampus. For instance, reelin-positive $\mathrm{CR}$ cells are still abundant in the stratum lacunosum-moleculare at P15 and P21, whereas they decrease in the adult hippocampus. Such a late loss of reelin expression correlates with previous quantitative studies using BrdU labeling and calretinin immunostaining, which indicate that hippocampal CR cells disappear between P15 and adult stages (Del Río et al., 1996; Supèr et al., 1998). Also, the persistence of relatively large numbers of calretinin-positive neurons in the adult stratum lacunosum-moleculare expressing reelin is consistent with quantitative data showing that up to $30 \%$ of hippocampal CR cells may survive in the adult hippocampus (Supèr et al., 1998). Because CR cells express neurotrophin receptors and appear to be responsive to BDNF (Marty et al., 1996; Brunstrom et al., 1997), the late and reduced loss of CR cells in the hippocampus might be related to the high expression of neurotrophic factors in this region or to certain developmental peculiarities, such as the prolonged postnatal neurogenesis of granule cells (Bayer, 1980).

\section{reelin and neuronal migration in the cerebral cortex}

The observation that reelin is expressed in most laminated forebrain regions is consistent with the notion that Reelin is essential for ordered neuronal migration and the normal arrangement of neurons in layers (D'Arcangelo et al., 1995; Ogawa et al., 1995). The present study shows that at E11-E18 reelin is expressed exclusively by CR cells in layer I, whereas at later stages prominent expression also occurs in middle cortical layers, especially in layers V and VI. The time of reelin expression in these layers (E18 on) is coincident with the period of neuronal migration for layers IV and II-III (Angevine and Sidman, 1961; Caviness, 1982; Fairén et al., 1986; Bayer and Altman, 1991), indicating that this second site of Reelin production may also contribute to the generation of the reeler phenotype.

CR cells have been implicated in the regulation of the radial glia phenotype (Soriano et al., 1997). However, Reelin is not the essential factor regulating the radial glia phenotype (Pinto-Lord et al., 1982; Hunter and Hatten, 1995; Hunter-Schaedle, 1997; Soriano et al., 1997). The migratory deficits in the reeler cerebral cortex are quite different from those in other migration abnormalities, such as lissencephaly (Reiner et al., 1995; Ecksloglu et al., 1996; des Portes et al., 1998; Gleeson et al., 1998). In fact, in 


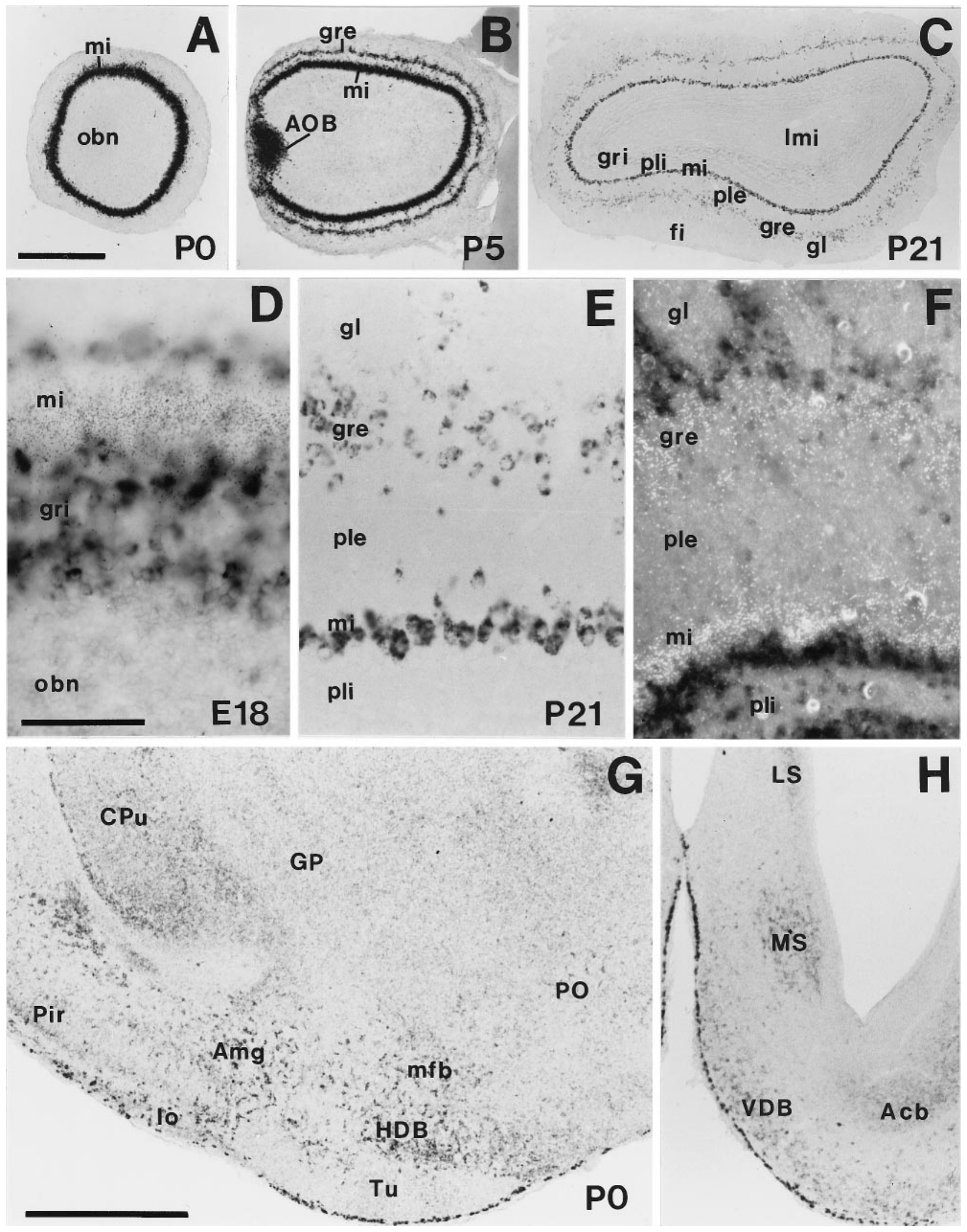

Figure 9. $A-C$, Low-power photomicrographs showing the patterns of reelin expression in the olfactory bulb at P0, P5, and P21. D, Double-labeled (radioactive and nonradioactive ISH) section illustrating the lack of colocalization between reelin mRNA (silver grains, mitral cells) and GAD67 expression (black, granule cells) in the olfactory bulb at E18. E, Photomicrograph showing the bilaminar distribution of reelin-expressing cells in the olfactory bulb at P21. F, Dark-field image of a double-labeled preparation (radioactive and nonradioactive ISH) of a field similar to that in $E$, showing the lack of colocalization between reelin mRNA (white labeling, silver grains) and GAD67 mRNA (black) in the olfactory bulb (Figure legend continues) 
reeler mice, migrating neurons appear to migrate successfully through the intermediate zone before reaching the cortical plate (Goffinet, 1979; Caviness, 1982; Pinto-Lord et al., 1982; Rakic and Caviness, 1995). Thus, the exit of migrating neurons from the ventricular zone and their initial migration through the intermediate zone appear to be largely Reelin independent.

It has been suggested that Reelin may provide a stop signal during development (Ogawa et al., 1995; Frotscher, 1997). However, the expression of reelin in middle cortical layers seems to be inconsistent for Reelin having such a role, at least for migrating neurons. Recent studies have implicated some attractive and repellent diffusible molecules, such as netrin-1 and semaphorin III, in the guidance of migrating neurons (Behar et al., 1996; Hu and Rutishauser, 1996; Serafini et al., 1996; Ackerman et al., 1997). We have shown previously that in culture experiments CR cells exert a chemoattractive influence on migrating cerebellar granule cells (Soriano et al., 1997). Because all migrating cortical neurons migrate toward layer I, CR cells secreting Reelin are in a suitable location to exert such a directional influence. Although Reelin is probably too large to diff use long distances, proteolytic processing might yield active soluble peptides of smaller sizes. If this is the case, the expression of reelin in middle cortical layers from E18 on might contribute efficiently to the generation of a Reelin gradient, especially as corticogenesis progresses and the cortex becomes thicker (D'Arcangelo and Curran, 1998).

\section{Other putative functions of Reelin in neural development: axonal growth}

We have recently shown that Reelin modulates the development of some hippocampal connections. Because this pathway does form in reeler mice, Reelin seems not to be essential for the ingrowth of these fibers, although it does regulate axonal branching and extension and synaptogenesis (Del Río et al., 1997).

In agreement with Schiffmann et al. (1997), there is a lack of correlation between some brain regions expressing reelin and the morphological abnormalities described in reeler mice. For instance, there is prominent reelin expression in the striatum, septum, and hypothalamus, regions in which previous studies failed to find cytoarchitectonic alterations in reeler mutant mice (Caviness et al., 1988). One explanation is that alterations to cell arrangement in these nuclei are too small to be detectable. Another possibility is that in these areas Reelin may play roles other than in cell migration.

The present study shows that in both embryonic and early postnatal periods, reelin expression is frequently associated with developing axonal tracts. For example, the dorsal thalamus/ventral thalamus boundary (zona limitans intrathalamica) gives rise to the external medullary lamina and the mammillothalamic tract, and the diencephalon/mesencephalon contains the neurons that pioneer the posterior commissure (Mastick and Easter, 1996; Kitamura et al., 1997). Similarly, in the telencephalon, reelin transcripts are present in cells located within developing olfactory-related pathways, including the lateral olfactory tract, the taenia tecta, the bed nucleus of the stria terminalis, and the medial forebrain bundle, and also in the entopeduncular area forming the internal capsule. Thus, the patterns of expression described in the present study are consistent with Reelin having a role in axonal growth or pathfinding, as proposed for other extracellular matrix proteins (Dorries et al., 1996; Gotz et al., 1996, 1997; Faissner et al., 1997).

\section{reelin expression in GABAergic neurons of the adult cerebral cortex}

A relevant finding of the present study is that reelin expression continues in the adult forebrain, which suggests the participation of Reelin in functions other than neural development. In the adult cerebral cortex, including the hippocampus, reelin expression is restricted to a subset of GABAergic local-circuit neurons, in agreement with the recent study of Pesold et al., (1998). Cortical GABAergic interneurons are subdivided into a large number of different cell types (de Felipe, 1993; Freund and Buzzáki, 1996; Cauli et al., 1997). The lack of colocalization of reelin and parvalbumin indicates that reelin is not expressed in basket or chandelier cells. In contrast, significant, although variable, percentages of interneurons immunoreactive for calbindin, calretinin, and the neuropeptides NPY and somatostatin express reelin. These interneurons form a rather heterogeneous population, but most of them are known to form inhibitory synaptic contacts on the dendritic domains of the principal neurons and thus are believed to exert a modulatory role on the principal neurons (de Felipe, 1993; Freund and Buzzáki, 1996).

We can only speculate about the functions of Reelin in the adult cerebral cortex. Some studies report that the cell bodies of certain cortical interneurons are covered by a rich extracellular matrix that may serve to anchor soluble molecules such as trophic factors (Celio and Blumcke, 1994). It is interesting to note that some neurotrophic factors, such as NGF and NT-3, are preferentially expressed by GABAergic interneurons in the adult cerebral cortex, and that subsets of these interneurons also express TrkB and TrkC receptors (Marty et al., 1996; Rocamora et al., 1996). Also, it is becoming increasingly clear that the biochemical machinery responsible for synaptic plasticity in GABAergic interneurons is substantially different from that in pyramidal cells (Maccaferri et al., 1998; Sik et al., 1998).

\section{Permanent reelin mRNA expression in the olfactory bulb}

Another region of prominent reelin expression in the adult is the olfactory bulb, with hybridization signals in mitral neurons and in some periglomerular neurons. Olfactory neurons are generated during the postnatal period and over the life-span of the animal. Progenitors fated to the olfactory bulb are located in the caudal telencephalic subventricular zone, so that migrating neurons move toward the olfactory bulb along a long rostral migratory pathway (Luskin, 1993; Lois and Alvarez-Buylla, 1994; Jankovski and Sotelo, 1996; Wichterle et al., 1997). The lack of reelin expression in the rostral migratory pathway suggests that this migration is Reelin independent, which agrees with studies reporting the presence of granule cells and periglomerular neurons in the olfactory bulb of reeler mice (Caviness and Sidman, 1972).

\section{$\longleftarrow$}

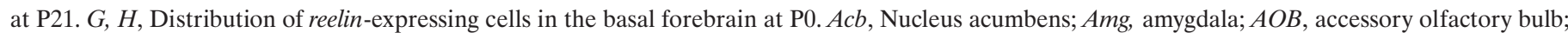

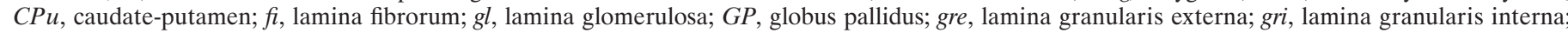

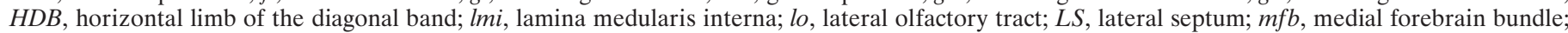

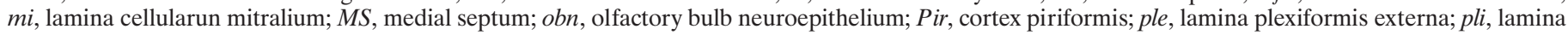

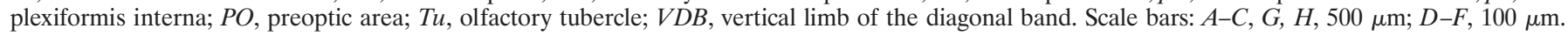



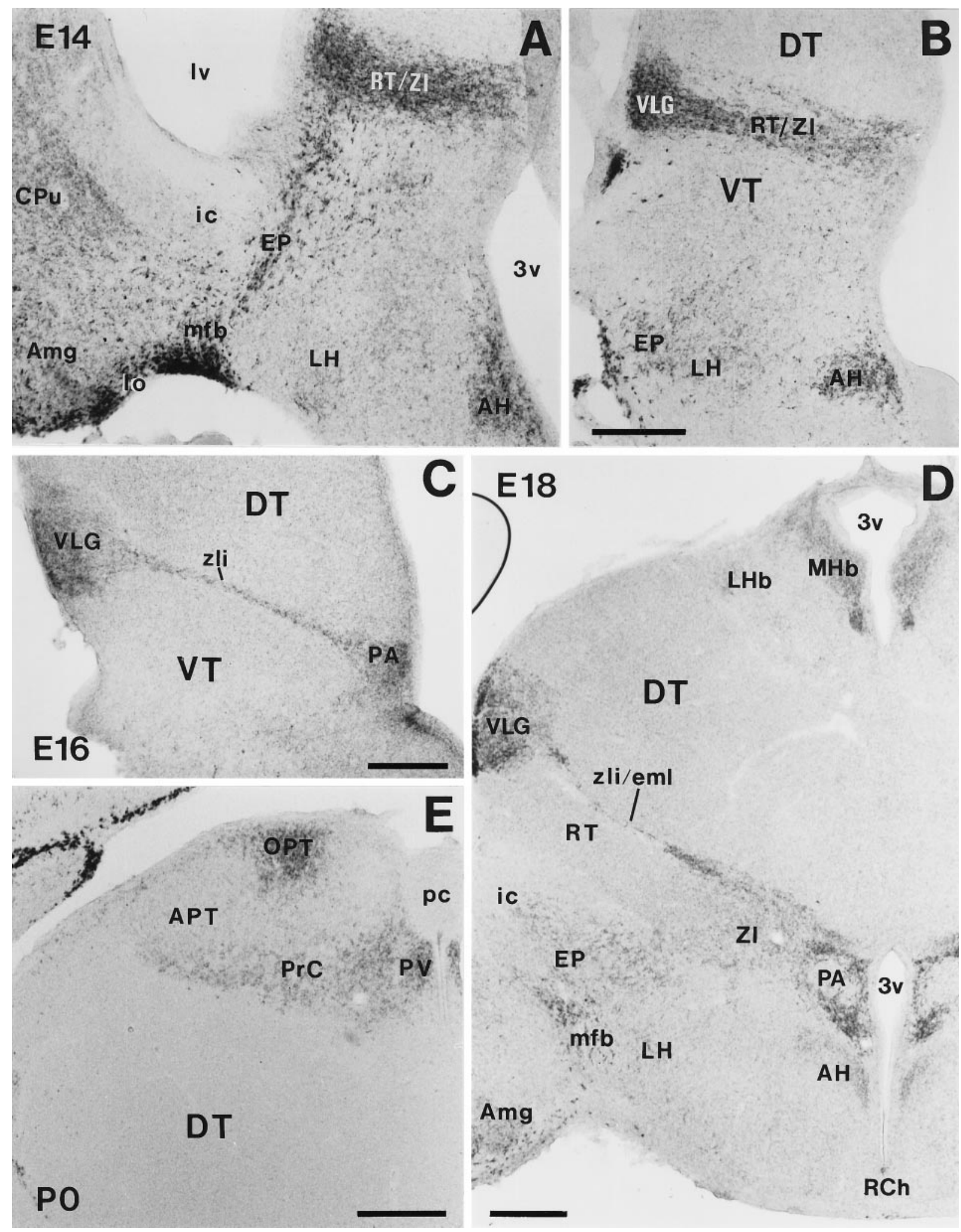

Figure 10. Developmental pattern of reelin mRNA expression in the diencephalon and hypothalamus. $A, B$, Photomicrographs illustrating two different rostrocaudal levels at E14, showing prominent reelin expression in the amygdala $(A m g)$, medial forebrain bundle ( $m f b)$, entopeduncular area $(E P)$, reticular nucleus/zona incerta $(R T / Z I)$, ventral lateral geniculate nucleus $(V L G)$, and anterior hypothalamic nucleus $(A H)$. $C$, At E16, reelin is expressed in the $V L G$, zona limitans intrathalamica $(z l i)$, and paraventricular hypothalamic nucleus $(P A) ; D$, At E18, reelin mRNA is expressed in the medial habenula $(M H b), V L G$, zona limitans intrathalamica/external medullary lamina (zli/eml), and $P A$; lower expression levels are detected in several other nuclei. $E$, reelin expression in the pretectum at P0. $A P T$, Anterior pretectal nucleus; $C P u$, caudate-putamen; $D T$, dorsal thalamus; $i c$, internal capsule; $L H$, lateral hypothalamus; $L H b$, lateral habenula; $l o$, lateral olfactory tract; $l v$, lateral ventricle; $O P T$, olivary pretectal nucleus; $p c$, posterior commissure; $\operatorname{PrC}$, nuclei of the posterior commissure; $P V$, paraventricular thalamic nucleus; $R C H$, retrochiasmatic area; $V T$, ventral thalamus; $3 v$, third ventricle. Scale bar, $250 \mu \mathrm{m}$. 
However, some of these neurons appear mispositioned in these mutants, which suggests a local action of olfactory bulb-derived Reelin in the last radial migratory phase of the neurons fated to the adult olfactory bulb.

The mature olfactory bulb is also a site of high synaptic growth and remodeling because of the neuroepithelial cell turnover and the inherent reinnervation of the glomeruli. Thus, it is possible that Reelin produced by periglomerular neurons may have a role in adult axonal growth, synaptogenesis, and plasticity.

In conclusion, the present study has shown complex regional and cellular patterns of reelin expression in the developing forebrain of the mouse, which are consistent with Reelin playing distinct roles in neural development. In addition, the finding that reelin is expressed in a subset of GABAergic local-circuit neurons in the adult cerebral cortex suggests novel, yet unknown, roles of Reelin in the normal functioning and neural plasticity in the adult brain that merit further investigation.

\section{REFERENCES}

Ackerman SL, Kozak LP, Przyborski SA, Rund LA, Boyer BB, Knowles BB (1997) The rostral cerebellar malformation gene encodes an UNC-5-like protein. Nature 386:838-842.

Angevine JB, Sidman RL (1961) Autoradiographic study of cell migration during histogenesis of cerebral cortex in the mouse. Nature 192:766-768.

Anton ES, Cameron RS, Rakic P (1996) Role of neuron-glial junctional domain proteins in the maintenance and termination of neuronal migration across the embryonic cerebral wall. J Neurosci 16:2283-2293.

Anton ES, Marchioni MA, Lee K-F, Rakic P (1997) Role of GGF/ neuroregulin signaling in interactions between migrating neurons and radial glia in the developing cerebral cortex. Development 124:3501-3510.

Barth PG (1987) Disorders of neuronal migration. Can J Neurol Sci $14: 1-16$.

Bayer SA (1980) Development of the hippocampal region in the rat. I. Neurogenesis examined with ${ }^{3} \mathrm{H}$-thymidine autoradiography. J Comp Neurol 190:87-114.

Bayer SA, Altman J (1991) Neocortical development. New York: Raven.

Behar O, Golden JA, Mashimo H, Schoen FJ, Fishman MC (1996) Semaphorin III is needed for normal patterning and growth of nerves, bones and heart. Nature 383:525-528.

Brunstrom JE, Gray-Swain MR, Osborne PA, Pearlman AL (1997) Neuronal heterotopias in the developing cerebral cortex produced by neurotrophin-4. Neuron 16:505-517.

Cameron RS, Rakic P (1994) Identification of membrane proteins that compromise the plasmalemmal junction between migrating neurons and radial glial cells. J Neurosci 14:3139-3155.

Cauli B, Audinat E, Lambolez B, Angulo MC, Ropert N, Tsuzuki K, Hestrin S, Rossier J (1997) Molecular and physiological diversity of cortical nonpyramidal cells. J Neurosci 17:3894-3906.

Caviness Jr VS (1982) Neocortical histogenesis in normal and reeler mice: a developmental study based upon $\left[{ }^{3} \mathrm{H}\right]$ thymidine autoradiography. Dev Brain Res 4:293-302.

Caviness Jr VS, Sidman RL (1972) Olfactory structures of the forebrain in the reeler mutant mouse. J Comp Neurol 145:85-104.

Caviness Jr VS, Sidman RL (1973) Time of origin of corresponding cell classes in the cerebral cortex of normal and mutant reeler mice: an autoradiographic analysis. J Comp Neurol 148:141-152.

Caviness Jr VS, Crandall JE, Edwards MA (1988) The reeler malformation. Implications for neocortical development: a view from mutations in mice. In: Cerebral cortex, Vol 7 (Jones EG, Peters A, eds), pp 59-89. New York: Plenum.

Celio MR, Blumcke I (1994) Perineuronal nets: a specialized form of extracellular matrix in the adult nervous system. Brain Res Rev 19:128-145.

Chae T, Kwon YT, Bronson R, Dikkes P, Li E, Tsai LH (1997) Mice lacking $\mathrm{p} 35$, a neuronal specific activator of $\mathrm{Cdk} 5$, display cortical lamination defects, seizures, and adult lethality. Neuron 18:29-42.

Chalepakis G, Wijnholds J, Giese P, Schachner M, Gruss P (1994) Characterization of pax- 6 and Hoxa-1 binding to the promoter region of the neural cell adhesion molecule L-1. DNA Cell Biol 13:891-900.
Chédotal A, Pourquié O, Sotelo S (1995) Initial tract formation in the brain of the chick embryo: selective expression of the BEN-GRASP cell adhesion molecule. Eur J Neurosci 7:198-212.

D'Arcangelo G, Curran T (1998) Reeler: new tales on an old mutant mouse. BioEssays 20:235-244.

D'Arcangelo G, Miao GG, Chen S-C, Soares HD, Morgan JI, Curran T (1995) A protein related to extracellular matrix proteins deleted in the mouse mutant reeler. Nature 374:719-723.

D'Arcangelo G, Nakajima K, Miyata T, Ogawa M, Mikoshiba K, Curran $\mathrm{T}$ (1997) Reelin is a secreted glycoprotein recognized by the CR-50 monoclonal antibody. J Neurosci 17:23-31.

De Carlos JA, O'Leary DDM (1992) Growth and targeting of subplate axons and establishment of major cortical pathways. J Neurosci 12:1194-1211.

de Felipe J (1993) Neocortical neuronal diversity: chemical heterogeneity revealed by colocalization studies of classic neurotransmitters, neuropeptides, calcium-binding proteins, and cell surface molecules. Cereb Cortex 3:273-289.

de Lecea L, Soriano E, Criado JR, Steffensen SL, Henriksen SJ, Sutcliffe JG (1994) Transcripts encoding a neural membrane CD26 peptidaselike protein are stimulated by synaptic activity. Mol Brain Res 25:286-296.

de Lecea L, Del Río JA, Criado JR, Alcántara S, Morales M, Henriksen SJ, Soriano E, Sutcliffe JG (1997) Cortistatin is expressed in a distinct subset of cortical interneurons. J Neurosci 17:5868-5880.

Del Río JA, Soriano E, Ferrer I (1992) Development of GABAimmunoreactivity in the neocortex of the mouse. J Comp Neurol 326:501-526.

Del Río JA, Martínez A, Fonseca M, Auladell C, Soriano E (1995) Glutamate-like immunoreactivity and fate of Cajal-Retzius cells in the murine cortex as identified with Calretinin antibody. Cereb Cortex 5:13-21.

Del Río JA, Heimrich B, Supèr H, Borrell V, Frotscher M, Soriano E (1996) Differential survival of Cajal-Retzius cells in organotypic slice cultures of neocortex and hippocampus. J Neurosci 16:6896-6907.

Del Río JA, Heimrich B, Borrell V, Forster, E, Drakew A, Alcántara S, Nakajima K, Miyata T, Ogawa M, Mikoshiba M, Derer P, Frotscher M, Soriano E (1997) A role for Cajal-Retzius cells and Reelin in the development of hippocampal connections. Nature 385:70-75.

Derer P (1985) Comparative localization of Cajal-Retzius cells in the neocortex of normal and reeler mutant mice fetuses. Neurosci Lett 54:1-6.

Derer P, Derer M (1990) Cajal-Retzius cell ontogenesis and death in mouse brain visualized with horseradish peroxidase and electron microscopy. Neuroscience 36:839-856.

Derer P, Derer M (1992) Development and fate of Cajal-Retzius cells in vivo and in vitro. In: Development of the central nervous system in vertebrates (Sharma SC, Goffinet AM, eds), pp 113-127. New York: Plenum.

des Portes V, Pinard JM, Billuart P, Vinet MC, Koulakoff A, Carrié A, Gelot A, Dupuis E, Motte J, Berwald-Netter Y, Catala M, Kahn A, Beldjord C, Chelly J (1998) A novel CNS gene required for neuronal migration and involved in X-linked subcortical laminar heterotopia and lissencephaly syndrome. Cell 92:51-61.

Dorries U, Taylor J, Xiao Z, Lochter A, Montag D, Schachner M (1996) Distinct effects of recombinant Tenascin-C domains in neural cell adhesion, growth cone guidance, and neuronal polarity. J Neurosci Res 43:420-438.

Edmunds SM, Parnavelas JG (1982) Retzius-Cajal cells: an ultrastructural study in the developing visual cortex of the rat. J Neurocytol 11:427-446.

Eksloglu YZ, Scheffer IE, Cardenas P, Knoll J, DiMario F, Ramsby G, Berg M, Kamuro K, Berkovic SF, Duyk GM, Parisi J, Huttenlocker PR, Walsh CA (1996) Periventricular heterotopia: an X-linked dominant epilepsy locus causing aberrant cerebral cortical development. Neuron 16:77-87.

Fairén A, Cobas A, Fonseca M (1986) Times of generation of glutamic acid decarboxylase immunoreactive neurons in mouse somatosensory cortex. J Comp Neurol 251:67-83.

Faissner A (1997) The Tenascin gene family in axon growth and guidance. Cell Tissue Res 290:331-341.

Feng L, Hatten ME, Heintz N (1994) Brain lipid-binding protein (BLBP): a novel signaling system in the developing mammalian CNS. Neuron 12:895-908. 
Fishell G, Hatten M E (1991) Astrotactin provides a receptor system for glia-guided neuronal migration. Development 113:755-765.

Freund TF, Buzzáki G (1996) Interneurons of the hippocampus. Hippocampus 6:347-470.

Frotscher M (1997) Dual role of Cajal-Retzius cells and Reelin in cortical development. Cell Tissue Res 290:315-322.

Gleeson JG, Allen KM, Fox JW, Lamperti ED, Berkovic S, Scheffer I, Cooper EC, Dobyns WB, Minnrath SR, Ross ME, Walsh CA (1998) doublecortin, a brain-specific gene mutated in human X-linked lissencephaly and double cortex syndrome, encodes a putative signaling protein. Cell 92:63-72.

Goffinet AM (1979) An early developmental defect in the cerebral cortex of the reeler mouse. A morphological study leading to a hypothesis concerning the action of the mutant gene. Anat Embryol 157:205-216.

Goffinet AM (1980) The cerebral cortex of the reeler embryo (an electron microscopic analysis). Anat Embryol 159:199-210.

Goffinet AM (1992) The reeler gene: a clue to brain development and evolution. Int J Dev Biol 36:101-107.

Gotz B, Scholze A, Clement A, Joester A, Schutte K, Wigger F, Frank R, Spiess E, Ekblom P, Faissner A (1996) Tenascin-C contains distinct adhesive, anti-adhesive, and neurite outgrowth promoting sites for neurons. J Cell Biol 132:681-699.

Gotz M, Bolz J, Joester A, Faissner A (1997) Tenascin-C synthesis and influence on axonal growth during rat cortical development. Eur J Neurosci 9:496-506.

Hatten ME (1993) The role of migration in central nervous system neuronal development. Curr Opin Neurobiol 3:38-44.

Hirotsune S, Takahara T, Sasaki N, Hirose K, Yoshiki A, Ohashi T, Kusakabe M, Murakami Y, Muramatsu M, Watanabe S, Nakao K, Katsuki M, Hayashizaki Y (1995) The reeler gene encodes a protein with an EGF-like motif expressed by pioneer neurons. Nat Genet 10:77-83.

Howell BW, Gertler FB, Cooper JA (1997a) Mouse disabled (mDab1): a Src binding domain implicated in neuronal development. EMBO J 16:121-132.

Howell BW, Hawkes R, Soriano P, Cooper JA (1997b) Neuronal position in the developing brain is regulated by mouse disabled-1. Nature 389:733-737.

$\mathrm{Hu}$ H, Rutishauser U (1996) A septum-derived chemorepulsive factor for migrating olfactory interneuron precursors. Neuron 16:933-940.

Hunter KE, Hatten ME (1995) A diffusible signal which regulates radial glial cell differentiation: identification and analysis using wild type and reeler mice. Soc Neurosci Abstr 21:315.6.

Hunter-Schaedle KE (1997) Radial glial cell development and transformation are disturbed in reeler forebrain. J Neurobiol 33:459-472.

Ikeda Y, Terashima T (1997) Expression of reelin, the gene responsible for the reeler mutation, in embryonic development and adulthood in the mouse. Dev Dyn 210:157-172.

Jankovski A, Sotelo C (1996) Subventricular zone-olfactory bulb migratory pathway in the adult mouse: cellular composition and specificity as determined by heterochronic and heterotopic transplantation. J Comp Neurol 371:376-396.

Kitamura K, Miura H, Yanazawa M, Miyashita T, Kato K (1997) Expression patterns of Brx1 (Rieg gene), Sonic hedgehog, Nkx2.2, Dlx1 and Arx during zona limitans intrathalamica and embryonic ventral lateral geniculate nuclear formation. Mech Dev 67:83-96.

Komuro H, Rakic P (1993) Modulation of neuronal migration by NMDA receptors. Science 260:95-97.

Lois C, Alvarez-Buylla A (1994) Long-distance neuronal migration in the adult mammalian brain. Science 264:1145-1148.

Lois C, Garcia-Verdugo J-M, Alvarez-Buylla A (1996) Chain migration of neuronal precursors. Science 271:978-981.

Luskin MB (1993) Restricted proliferation and migration of postnatally generated neurons derived from the forebrain subventricular zone. Neuron 11:173-189.

Maccaferri G, Toth K, McBain CJ (1998) Target-specific expression of presynaptic mossy fiber plasticity. Science 279:1368-1370.

Mariani J, Crepel F, Mikoshiba K, Changeux JP, Sotelo C (1977) Anatomical, physiological and biochemical studies of the cerebellum from reeler mutant mouse. Philos Trans R Soc Lond B Biol Sci 281:1-28.

Marín-Padilla M (1971) Early prenatal ontogenesis of the cerebral cortex (neocortex) of the Felix domestica. A Golgi study. I. The primordial neocortical organization. Z Anat Entwicklungsgesch 134:117-145.

Marín-Padilla M (1972) Prenatal ontogenic history of the principal neurons of the neocortex of the cat (Felix domestica). A Golgi study. II.
Developmental differences and their significance. Z Anat Entwicklungsgesch 136:125-142.

Marín-Padilla M (1984) Neurons of layer I. A developmental analysis. In: Cerebral Cortex, Vol I, Cellular Components of the Cerebral Cortex (Peters A, Jones EG, eds), pp 447-478. New York: Plenum.

Marín-Padilla M (1998) Cajal-Retzius cells and the development of the neocortex. Trends Neurosci 21:64-71.

Marty S, Carroll P, Cellerino A, Castren E, Staiger V, Thoenen H, Lindholm D (1996) Brain-derived neurotrophic factor promotes the differentiation of various hippocampal nonpyramidal neurons, including Cajal-Retzius cells, in organotypic slice cultures. J Neurosci 16:675-687.

Mastick GS, Easter Jr SS (1996) Initial organization of neurons and tracts in the embryonic mouse fore- and midbrain. Dev Biol 173:79-94.

Mastick GS, Davis NS, Andrews GL, Easter Jr SS (1997) Pax-6 functions in boundary formation and axon guidance in the embryonic mouse forebrain. Development 124:1985-1997.

Nakajima N, Mikoshiba K, Miyata T, Kudo C, Ogawa M (1997) Disruption of hippocampal development in vivo by CR-50 mAb against Reelin. Proc Natl Acad Sci USA 94:8196-8201.

Ogawa M, Miyata T, Nakajima K, Yagyu K, Seike M, Ikenaka K, Yamamoto H, Mikoshiba K (1995) The reeler gene-associated antigen on Cajal-Retzius neurons is a crucial molecule for laminar organization of cortical neurons. Neuron 14:899-912.

Oshima T, Ward JM, Huh CG, Longenecker G, Veeranna, Pant HC, Brady RO, Martin LJ, Kulkarni AB (1996) Targeted disruption of the cyclin-dependent kinase 5 gene results in abnormal corticogenesis, neuronal pathology and perinatal death. Proc Natl Acad Sci USA 93:11173-11178.

Paxinos G, Törk I, Tecott LH, Valentino KL (1994) Atlas of the developing rat brain. Los Angeles: Academic.

Pesold C, Impagnatiello F, Pisu MG, Uzunov DP, Costa E, Guidotti A, Caruncho HJ (1998) reelin is preferentially expressed in neurons synthesizing $\gamma$-aminobutyric acid in cortex and hippocampus of adult rats. Proc Natl Acad Sci USA 95:3221-3226.

Pinto-Lord MC, Evrard P, Caviness Jr VS (1982) Obstructed neuronal migration along radial glial fibers in the neocortex of the reeler mouse: a Golgi-EM analysis. Dev Brain Res 4:379-393.

Puelles L, Rubenstein JLR (1993) Expression patterns of homeobox and other putative regulatory genes in the embryonic mouse forebrain suggest a neuromeric organization. Trends Neurosci 16:472-479.

Rakic P (1974) Neurons in rhesus monkey visual cortex: systematic relation between time and origin and eventual disposition. Science 183:425-427.

Rakic P (1988) Specification of cerebral cortical areas. Science 241:170-176.

Rakic P (1990) Principles of neural cell migration. Experientia 46:882-891.

Rakic P, Caviness Jr VS (1995) Cortical development: view from neurological mutants two decades later. Neuron 14:1101-1103.

Reiner O, Albrecht U, Gordon M, Chianese KA, Wong C, Gal-Gerber O, Sapir T, Siracusa LD, Buchberg AM, Caskey CT, Eichele G (1995) Lissencephaly gene (LIS1) expression in the CNS suggests a role in neuronal migration. J Neurosci 15:3730-3738.

Rio C, Rieff HI, Qi PM, Corfas G (1997) Neuregulin and erbB receptors play a critical role in neuronal migration. Neuron 19:39-50.

Rocamora N, Pascual M, Acksády L, de Lecea L, Freund TF, Soriano E (1996) Expression of NGF and NT3 mRNA in hippocampal interneurons innervated by the GABAergic septo hippocampal pathway. J Neurosci 16:3991-4004.

Schiffmann SN, Bernier B, Goffinet A (1997) reelin mRNA expression during mouse brain development. Eur J Neurosci 9:1055-1071.

Serafini T, Colamarino SA, Leonardo ED, Wang H, Beddington R, Skarnes WC, Tessier-Lavigne M (1996) Netrin-1 is required for commissural axon guidance in the developing vertebrate nervous system. Cell 87:1001-1014.

Sheldon M, Rice DS, D’Arcangelo G, Yoneshima H, Nakajima K, Mikoshiba K, Howell BW, Cooper JA, Goldowitz D, Curran T (1997) Scrambler and yotari disrupt the disabled gene and produce a reeler-like phenotype in mice. Nature 389:730-733.

Sidman RL, Angevine Jr JB, Taber-Pierce E (1971) Atlas of the mouse brain and spinal cord. Cambridge, MA: Harvard UP.

Sik A, Hajos N, Gulacsi A, Mody I, Freund TF (1998) The absence of a major $\mathrm{Ca}^{2+}$ signaling pathway in GABAergic neurons of the hippocampus. Proc Natl Acad Sci USA 95:3245-3250. 
Soriano E, Del Río J A, Martínez A, Supèr H (1994) Organization of the embryonic and early postnatal murine hippocampus. I. Immunocytochemical characterization of neuronal populations in the subplate and marginal zone. J Comp Neurol 342:571-595.

Soriano S, Alvarado-Mallart RM, Dumesnil N, Del Rio JA, Sotelo C (1997) Cajal-Retzius cells regulate the radial glia phenotype in the adult and developing cerebellum and alter granule cell migration. Neuron 18:563-577.

Stoykova A, Götz M, Gruss P, Price J (1997) Pax-6-dependent regulation of adhesive patterning, R-Cadherin expression and boundary formation in developing forebrain. Development 3765-3777.

Supèr H, Martínez A, Del Río JA, Soriano E (1998) Involvement of distinct pioneer neurons in the formation of layer-specific connections in the hippocampus. J Neurosci 18:4616-4626.
Ware ML, Fox JW, Gonzalez JL, Davis NM, Deroubroit CM, Russo CJ, Chua SC, Goffinet AM, Walsh CA (1997) Aberrant splicing of a mouse disabled homolog, mdab1, in the scrambler mouse. Neuron 19:239-249.

Wichterle H, García-Verdugo JM, Alvarez-Buylla A (1997) Direct evidence for homotypic, glia-independent neuronal migration. Neuron 18:779-791.

Wilson SW, Placzek M, Furley AJ (1993) Border disputes: do boundaries play a role in growth-cone guidance?. Trends Neurosci 16:316-323.

Zheng C, Heintz N, Hatten ME (1996) CNS gene encoding Astrotactin, which supports neuronal migration along glial fibers. Science 272:417-419.

Zilles K (1985) The cortex of the rat. A stereotaxic atlas. Berlin: Springer. 